\title{
Dünyada ve Türkiye'de Adsız Alkolikler
}

\author{
Alcoholic Anonymous in the World and in Turkey
}

\author{
Abdullah Yıldız ${ }^{1 \text { iD }}$ \\ 1. Ankara Üniversitesi Tıp Fakültesi Tıp Tarihi ve Etik Anabilim Dalı, Ankara, Türkiye
}

\begin{abstract}
Self-support groups have an important role in different dimensions in the treatment of alcohol dependence. The best known of these groups is the Alcoholics Anonymous (AA). In this study, the historical development, philosophy and important concepts of anonymous alcoholics are explained and their relationship with psychiatry is mentioned. However, it is thought that it is important to make a short introduction to the history of Alcohol and Alcohol Addiction in terms of determining the place and importance of the AA group in the historical process. The literature on alcohol, alcohol addiction and AA has been reviewed from a medical history perspective. Historical findings on alcohol addiction date back to antiquity. The relationship between the modern concept of alcohol addiction and medicine is parallel with the development of modern psychiatry. At the beginning of the 20th century, it is seen that religious groups are active in alcohol addiction. While AA took a different approach in this process, it gained a privileged place. Since the middle of the 20th century, it has been in interaction with modern medicine and psychiatry and has made important contributions to addiction. The development of AA in Turkey is relatively new and has encouraged the establishment of other groups. In conclusion, AA has a historically important place in the development of alcohol addiction treatment. The group's philosophical orientation and its relationships with addiction psychiatry have been important in this context.
\end{abstract}

Keywords: Alcoholic Anonymous, alcohol use disorder, history of psychiatry

Öz

Kendine destek grupları alkol bağımlıı̆ı tedavisinde farklı boyutlar içinde önemli bir yere sahiptirler. Bunlardan en bilineni Adsız Alkolikler (AA) grubudur. Bu çalışmada AA'nın tarihsel gelişimi, felsefesi, önemli kavramları ve psikiyatriyle ilişkisi değerlendirilecek ve Türkiye'deki gelişiminden de kısaca bahsedilecektir. Ancak AA grubunun tarihsel süreçteki yeri ve öneminin belirlenmesi açısından Alkol ve Alkol Bağımlıı̆̆ tarihine ilişkin kısa bir girişin yapılmasının da önemli olduğu düșünülmüştür. Alkol, alkol bağımlılı̆ı ve AA'ya ilişkin olarak tıp tarihi perspektifinden literatür taranmıştır. Alkol bağımlılı̆ına ilişkin tarihsel bulguların geçmişi antik çağa dayanır. Modern alkol bağımlılığı kavramı ile tıbbın ilişkisi modern psikiyatrinin gelişimi ile paraleldir. XX. yüzylın başlarında alkol bağımlılığ konusunda dini grupların etkin olduğu görülmektedir. AA bu süreçte farklı bir yaklaşım sergilerken ayrıcalıkı bir yer edinmiştir. XX. yüzylın ortalarından itibaren de modern tıp ve psikiyatri ile etkileşim içinde olmuş ve bağımlılığa ilişkin önemli katkılar sunmuştur. AA Türkiye'deki gelişimi görece yenidir ve başka grupların kurulmasını teşvik etmiştir. Sonuç olarak, AA grubunun alkol bağımlılığı tedavisinin gelişim sürecinde tarihsel düzeyde önemli bir yere sahiptir. Grubun felsefi yönelimi ve bağımlılık psikiyatrisi ile ilişkileri bu bağlamda önemli olmuştur.

Anahtar kelimeler: Adsız Alkolikler, alkol kullanım bozukluğu, psikiyatri tarihi 


\section{Giriş}

Alkol, uzun zamandır farklı amaçlarla insanlığın tüketiminde olan bir maddedir. Pek çok kültürün ve yaşantının içerisinde yer almıştır ve halen yer almaktadır. Sahip olduğu uzun tarihsel geçmiş içerisinde, eğlence amacıyla, dini amaçlarla ve tıbbi amaçlarla kullanılmıştır $(1,2)$. Tıbbi amaçla kullanımı yanında ve ilginç bir biçimde tıbbi tedaviye intiyaç gösteren türden bağımlılık yapan bir madde olması özelliğiyle de bilinmektedir. Uzun süreli ve genellikle yüksek miktarlardaki kullanımına bağlı olarak, özellikle kişinin alkol tüketimi üzerindeki kontrolünü kaybettiği bir tablo olan bağımlılık ortaya çıkmaktadır (3).

Tarihsel süreç içerisinde alkol elde etme yöntemlerinde yaşanan gelişmeler ve endüstrileşme ile birlikte alkolün tüketim miktarı da artış göstermiştir. Bu artışa paralel olarak alkol bağımlıı̆̆ bir sorun olarak toplumun ve tıbbın gündemine girmiş ve son 200 yıllık tarihsel süreçte bu gelişmeler hız kazanmıştır (4). Bağımlılık konusunda tıbbi çalışmalar özellikle Amerika Birleşik Devletleri'nde yoğun bir şekilde sürdürülmüştür (5).

Alkol tüketimindeki artış, toplumun belli kesimlerince birçok olumsuzluğun nedeni olarak gösterilmiştir. Dolayısıyla devletler zaman zaman kısıtlama yollarına da gitmişlerdir. Toplumsal baskı, devlet politikaları ve tıbbın alkol bağımlılığına olan bakışı arasında uzlaşmazlıklar nedeniyle 20. yüzyılın başlarında bağımlılık, tıbbi anlamda görece geri plana itilmiştir. Tıp, bağımlılı̆ı bilimsel bir temelde ele almaya çalışırken, toplumsal baskı unsurları bu sorunu ahlaki düzeyde ele alıp birçok olumsuzlukla özdeşleştirmiştir. Dolayısılyla devlet politikaları baskı unsurlarından etkilenerek yapılmıştır $(4,5)$. Bu dönemde alkol sorunu yaşayan bireyler farkı yollardan yardım aramaya başlamak durumunda kalmışlardır. Özellikle dini yönelimli gruplar içerisinde yardım aranmıştır. Ancak bu grupların sorun yaşayan bireylere tam anlamılla yardım sağlayamadığı görülmüştür (6).

Alkol bağımlılı̆ı ile birlikte konumuzun odağını oluşturan Adsı Alkolikler (AA) Grubu alkol sorunu yaşayan bireylere yine alkol sorunu yaşayan bireylerin deneyimlerinden yola çıklarak ve bir birliktelik sağlanarak yardım sağlanabileceği düşüncesi ile 1930’ların ortasında kurulmuştur (6). Kendinden önceki gruplardan düşünsel anlamda farklılaşan bu grup, alkol sorununa yönelik başarılı bir örnek oluşturmuş ve uyguladığı yöntemler tıp profesyonelleri tarafından da kabul görmüştür. AA grubunun kurulması bağımlılık konusunun yeniden bilimsel dünyanın gündemine oturmasına yardımcı olduğu gibi, kendine yardım pratiği için birçok farklı alana esin kaynağı olmuştur. Kurulduğu günden bugüne neredeyse tüm dünyaya yayılmış olan bu grup çok sayıda üyeye sahiptir $(7,8)$. Bu çalışmada alkol bağımlılı̆ı tarihine ilişkin genel bir perspektif verilmesi, alkol bağımlılı̆ı tedavisinde önemli katkıları bulunan ve dünyanın en büyük kendine yardım grubu olan AA hakkında tarihsel ve güncel bir çerçeve sunulması amaçlanmışıır.

\section{Alkol Nedir?}

Alkol, meyve, sebze veya tahılların bakteriler tarafından gerçekleştirilen fermantasyonları sonucunda doğal olarak oluşabilen ve farklı formları mevcut olan bir maddedir. Oluşma süreci üretim basamaklarının planlanması sonucu hızlandırılabilir. İnsan kullanımı için üretilen alkol, etil alkol ya da etanol olarak bilinir ve basit bir moleküler yapıya $\left(\mathrm{C}_{2} \mathrm{H}_{5} \mathrm{OH}\right)$ sahiptir. Alkol, uzun süre ve yüksek dozlarda kullanımına bağlı olarak toksik olabilen bir moleküldür (9). Tüketilen alkol, mide ve bağırsak mukozası araclığıyla dolaşım sistemine girmektedir. Dolaşım sistemi sayesinde bütün vücuda yayılan alkolün en belirgin etkileri beyin üzerine olmaktadır (7). Bu etkileri yanında alkol, zaman içerisinde tolerans gelişimine neden olan, santral sinir sistemi yapısında değişiklikler meydana getiren, buna paralel olarak davranış sorunları ve çekilme belirtileriyle birlikte seyreden bağımlılığa neden olan maddelerdendir (3).

\section{Alkolün Kısa Tarihi}

İnsanlar tarafından kullanılan ve günümüzde bağımlılık yaptıkları bilinen maddelerin çoğu insanlık tarihinin 
de önemli bir parçası olagelmiştir (1). Bu maddelerden birisi olan alkol, insanlık tarihi içerisinde önemli bir tüketim aracı ve dolayısıyla kültür unsuru olmuştur. Bu özelliğine ek olarak, gerek tıbbi amaçlı kullanımı, gerekse yemek ve eğlencelerde tüketilmiş olması alkolün sıkça tartışmalara konu olmasına yol açmıştır. Bazı kültürlerde kutsal bir içecek, bazılarında toplum kullanımına yasaklanmış bir madde ve bazı toplumlarda ise törensel amaçlarla kullanılan bir unsur olma özelliğine sahiptir (2). Alkol uzunca bir süre tıbbi amaçlar için kullanılmıştır, günümüzde de örneğin dezenfeksiyon gibi önemli bir amaçla işlev görmektedir (10).

Alkol tarihsel süreç içerisinde üretim alanındaki gelişmeler sonucunda farklı formlarda ve daha kolay elde edilmeye başlanmıştır. Alkolün ilk defa ne zaman üretildiğine ilişkin kesin bir bilgi yoktur; ancak ilk olarak baldan, dut ve böğürtlen gibi meyvelerden elde edilmiş olabileceği düşünülmektedir. Bira üretimiyle ilgili veriler M.0̈. 8000'lere kadar geriye gidebildiğinden yaklaşık 10.000 yıldır insanın alkol elde edebildiği düşünülmektedir (4). Bu gelişmelerin tarıma geçişin başladığı Yakın Doğu'da gerçekleştiği, hatta ekmek üretiminden önce bira üretiminin amaçlanmış olabileceği iddia edilmiştir (11). Çin'de de alkol üretildiğine dair kanıllar vardır, ancak tarihsel olarak M.Ö. 7.000-6.000'e dayanmaktadır. Şarap üretiminin ise biradan sonra başladığı ifade edilmektedir. Alkolün kullanımına ilişkin ilk yazılı metinlere Antik Mısır piktograflarında rastlanmaktadır. Bu metinlerde biranın günlük kullanıma sahip olduğu görülmüştür (4). Alkol tüketiminin göçebe toplumlarda görece az olduğu, ancak yerleşik hayata geçiş ile birlikte belirgin şekilde gündelik hayatın bir parçası haline geldiği söylenebilir. Bu dönem yukarıda bahsedilen dönem olan neolitik dönemle (M.Ö. 10.000-4.000) uyumludur. Alkolün üretimi genel olarak şarap ve bira üreticilerinin doğal fermantasyon yöntemlerini kullanmasıyla gerçekleşmiş olsa da fermantasyonun biyolojik olarak nasıl gerçekleştiğinin öğrenilmesi için Louis Pasteur'un şarap ile yaptığı çalışmaların beklenmesi gerekmiştir. Başlangıçta insanların kazara fermantasyon ile alkol elde ettiklerini söylemek mümkünken, zaman içerisinde kendileri bu fermantasyon yöntemlerini kullanmışlardır (12).

Tarihsel ve toplumsal bağlam içerisinde alkolün anlamı da sürekli olarak değişiklik göstermiştir. Zaman zaman iyilik hali, eğlence, neşe, doğurganlık ve aşkınlık kaynağı olarak görülürken, bazen de toplumsal bozulma, şiddet ve ahlaksızlık ile ilişkilendirilmiştir. Bazı toplumlarda ise şarap ve bira tanrılarla ilişkilendirilmiştir. Sümer tanrısı Ninkasi'ye adanmış metinlerde Ninkasi'nin bira tanrısı olduğu ve biranın nasıl yapılacağını anlattığı belirtilmektedir. Mısır tanrısı Osiris'in şarap ve birayı insanlığa bağışladığı belirtilmiş, Antik Yunan'da Dionysus ve Roma'da Bacchus bira ve şarapla ilişkilendirilmiş̧tir (12). Hıristiyanlık ve Yahudilik gibi dinlerde şarabın Nuh tarafından büyük tufandan sonra elde edildiği ifade edilirken (13), Babil kaynaklarında benzer bir hikâyede bira ve şarabın gemi inşası sırasında kullanıldı̆ı belirtilmiştir (12). Yerleşik hayata geçilmesi, amfora, terrakota gibi çömlek ve seramik vazoların yapılması alkol üretiminin ve ticaretinin yaygınlaşmasında önemli rol oynamıştır. Bu aletlerin incelenmesi ile M.Ö. 7.000-6.000'lerde şarabın kullanılmış olduğu görülmüştür (13).

Antik Mısır'da şarabın M.Ö. 4000'lerde tüketilmekte olduğu, biranın önemli bir enerji kaynağı olarak görüldüğü ve özellikle piramit yapımında çalışan işçilerce bu amaçla içildiği belirtilmektedir (4). Antik Mısır'da bu dönemde alkole ilişkin algının ıımlı olduğu ve yaygın bir kullanıma sahip olduğu anlaşılmaktadır. Gerek biranın gerekse şarabın farklı formları mevcut olup, beslenme ve tıbbi amaçlarla kullanımının yanısıra eğlence ve ücret ödeme aracı olarak da kullanılmıştır (4). İbranilerin de alkol ile ilişkilerinin Mısır'da başladığı düşünülmektedir. Hatta İbranilerin Musa ile Mısır'dan çıkarlarken şarabı geride bıraktıklarına üzüldükleri, ancak yeni topraklarında üzüm bağlarını görünce memnun oldukları ifade edilmiştir (14).

M.0̈. 1.000'lerde Atlantik'in karşı kıyılarında günümüz Meksika'sında yaşayan Mayalar gibi halkların da alkol tükettikleri belirlenmiştir (2). Antik Çin'de de alkol gerek dini gerekse toplumsal hayatın önemli bir parçası olmuştur. Hatta abartılı olmamak kaydıyla alkol kullanımını teşvik eden fermanlardan bahsedilmektedir. Dolayısıyla alkolün gündelik hayatın önemli bir unsuru olduğu söylenebilir. Bu durumun Marco Polo'nun (1254-1324) gezilerine kadar devam etmiş olduğu ifade edilmektedir (4). Babil'de ise temel alkollü içki bira olmakla birlikte, şarap da geniş bir kullanım alanına sahipti. Ayrıca Hammurabi Kanunları'nda adil alkol ticaretine ilişkin ifadeler yer almıştır (15). 
Şarap imalatının M.Ö. 2000'lerde Antik Yunan'a ulaştı̆ı ve şarabın 300 yıl gibi bir süre içinde yaygın bir tüketim alanı bulduğu bilinmektedir. Antik Yunan'da şarap tanrılara sunulan bir içecek olduğu gibi, bir ticari değiş tokuş aracı olarak da kullanılmıştır. Zaman içinde şarap toplumsal ve gündelik yaşamın önemli bir parçası haline gelmiştir. Genel olarak Antik Yunan'da sarhoşluk veren miktarda içmeye kötü gözle bakılmış, ancak ıımlı düzeydeki alkol tüketimi hoş görülmüştür (4). Platon'un (M.Ö. 429-347) da içinde yer aldığı bazı filozoflar az miktarda alkol tüketimine olumlu yaklaşmışlar; fakat belli sınırlar çizilmesi gerektiğini de ifade etmişlerdir (16). Örneğin Platon; 18 yaşından önce, askeri görev sırasında, devlet yöneticileri ve hakimler gibi meslek mensupları için çalışma esnasında alkol alınmasının uygun olmayacağını belirtmiştir (17). Sarhoşluğun insanı tanrılara yaklaştırdığını düşünenler de olmuştur. Olasılıkla bu düşünce Şarap Tanrısı Dionysus kültünden dayanak almıştır (4). Özellikle M.Ö. VI. yüzylldan itibaren şarap tüm dünyada yaygın bir şekilde kullanıımış ve enerji kaynağı olmuştur. Pers bölgesinde de yöneticiler fazla miktarda olmamak koşulu ile alkol tüketimini olumlu karşılamışlardır (4). Romalıların ise Roma'nın kurulmasından itibaren alkol tükettikleri bilinmektedir. Roma'da alkol tüketim miktarları özellikle M.Ö. I. yüzyıl ve M.S. I. yüzyıl arasında oldukça yüksek oranlara ulaşmıştır. Bu dönemde devletin üst düzeyinden ünlü kişilerin alkolik olarak nitelendirildiği ifade edilmiştir. Zaman içerisinde alkol tüketiminde ve alkol sorunu yaşanmasında gerileme olmuştur (18).

Hıristiyanlığın yayılmasıyla birlikte Hıristiyan değer ve düşünce sistemi etkili olmaya başlamıştır. Bu düşünce sisteminde İsa'nın şarap tükettiği bilindiğinden şarap önemsenmiştir. Ancak yine İsa'nın sarhoşluğu hoş karșılamadığı ifade edilmiștir. Aziz Paul'e göre, şarap tanrısal bir içecek olduğundan doğal olarak iyi görülmüştür. Alkole ilişkin bu tutum tıbbi amaçlı kullanımını da kolaylaştırmıştır. Ancak alkole ilişkin olarak sarhoşluk kınanmış ve alkol tüketimini kontrol edemeyenlerin içmemesi önerilmiştir (4). Genel olarak Hıristiyanlık alkol tüketimini yasaklamadığı gibi, Hıristiyanlığın özellikle aşırı olmamak kaydıyla şarap tüketimine olumlu baktığı yaygın bir kabuldür (16).

Anglo-Sakson dünyada alkol genellikle içki salonlarında tüketilmiştir. Hemen her yerleşim yerinde böyle yapılar yer almıştır. Bu yapılar doğal olarak kültürün de önemli öğelerini oluşturmuşlardır. Hun akınları sonrasında V. yüzyılda bu tür yerleşim yerlerinin kısa süre kesintiye uğradığı ifade ediliyor olsa da sonradan da varlıklarını sürdürmüşlerdir. X. ve XV. yüzyıllar arasında Avrupa'da özellikle bira tüketiminde artış yaşanmıştır. Aynı zamanda Fransa başta olmak üzere şarap ticareti gelişmiştir (2). Ortaçağ boyunca alkol ile ilgili olarak yaşanmış en önemli gelişmelerden birisi distilasyon yönteminin geliştirilmesidir. Bu yöntemin ilk olarak kimler tarafından geliştirildiğine ilişkin kesin bir uzlaşı olmamakla birlikte yaygın kanı Arapçanın bilim dili olarak kullanıldığı dönem içerisinde bu konuda öncü çalışmalar yapıımış olduğudur (19). Özellikle Cabir İbn Hayyan (Ö:815), Razi (865-925) ve Zehravi (936-1013) gibi isimler alkol konusunda önemli çalışmalar yapmışlardır. Razi alkol kelimesini distilasyon sonrasında elde ettiği şarabın özü anlamında kullanmıştır. Alkol kelimesi diğer dillere Arapçadan geçmiştir. Zehravi de alkolün insan üzerindeki etkileri üzerine çalışmıştır (2). Distilasyonun öğrenilmesinden sonra alkolün tıbbi amaçlı kullanımına olan ilgide artış meydana gelmiştir. Örneğin bir tıp hocası olan Arnold de Villanova (1240-1311), distile edilmiş alkolü hayat iksiri olarak nitelendirmiş, yaşamı uzattığını ve doğumu kolaylaştırdığını ifade etmiştir (20).

Keşif öncesi Amerika kıtasında fermantasyon ile alkol üretimi ve alkol tüketimi olmakla birlikte keşif sonrasında batılı tarzdaki alkol üretim ve tüketimi Amerika'ya ulaşmıştır (4). Katolik dünya başta olmak üzere, Batı dünyasında alkole genel olarak olumsuz yaklaşılmamış, hatta Tanrı bağışı olarak görülmüştür. Ancak aşıı tüketim ve sarhoşluk hoş görülmemiştir. İlam dünyasında ise alkolün az miktarı bile hoş görülmemiş olmakla birlikte alkole ilişkin dini düşünce ile bilimsel, rasyonel düşünce ve edebiyattaki alkole yaklaşım arasında kafa karıştırıcı bir ilişkinin olduğu söylenebilir $(2,4)$.

On yedinci yüzyıldan itibaren şeker üretiminin artışı ile birlikte alkol üretiminde de artış yaşanmışıı. Süreç içerisinde artan alkol üretimine paralel olarak sarhoşluk ve ilişkili sorunlarda yaşanan artış, alkole ilişkin endişeleri artırmıştır (4). Ayrıca yüksek kalorili olması nedeniyle endüstri devrimi sonrasında da önemli bir yer edinen alkol, zaman içinde sarhoşluğun önemli bir sorun haline gelmesiyle olumsuz bir bakışla değerlendirilir olmuştur $(6,21)$. 
On dokuzuncu yüzyılın ikinci yarısından itibaren özellikle Protestan Kiliselerinden Hıristiyanlığın alkole ilişkin geleneksel görüşlerine tepkiler gelmeye başlamıştır. Öğretilerinde alkol ile ilgili olarak zararlı ve günaha sokan bir madde söylemi kullanılmıştır. İncil'de tasvir edilen şarap içen İsa imgesinin ortaya çıkardığı çelişkiyi aşmak için de iki farkı şaraptan bahsetmişılerdir. İlkinin tanrının armağanı olan ve İsa'nın kutsadığı üzüm suyu olduğu, ikincisinin ise sarhoşluk veren şarap olduğu belirtilmiştir. Böylece 0 zamana kadar kutsal kabul edilmiş olan içecek bir anda olumsuz bir görünüme sahip olmuştur (4). Zaman içerisinde, suç, kötü davranışlar, ahlaki ve sosyal sorunlar gibi bireysel ve toplumsal problemler alkol ile ilişkilendirilmiştir. Böylece XIX. yüzyıl içinde dünyanın birçok yerinde içki içmeyen ve alkol karşıtı olan gruplar ortaya çıkmıştır. Bu gruplar dini, politik, gönüllü ve bilimsel görünümlere bürünmüş karmaşık yapılar halindedirler. Zaman içerisinde özellikle İngilizce konuşulan ülkeler başta olmak üzere uluslararası düzeyde faaliyetler göstermişlerdir. Kiliseye bağlı kadın örgütleri de bu gruplar içinde önemli işlevler üstlenmişlerdir (22). Başlangıçta gönüllü olarak alkol tüketilmemesini önermiş olsalar da zaman içerisinde baskı unsurlarına dönüşerek alkol tüketilmesinin yasaklanmasını talep etmişlerdir. Bazı ülkelerde yasaklamalara gidilmesine rağmen alkole ilişkin sorunların tam olarak ortadan kaldırılamadığı gözlenmiştir (4). Ancak konuya ilişkin çabalar sürdürülmüştür. 1935 yılına gelindiğinde ise çalışmamızın da bir parçasını oluşturan Adsız Alkolikler kurulmuştur. Alkol bağımlılığı ile mücadeleye odaklanmış olan bu oluşum zaman içerisinde neredeyse tüm dünyaya yayılan bir büyüklüğe ulaşmıştır $(4,6)$.

\section{Alkol Bağımlılığı ve Tedavisinin Tarihsel Gelişimi}

Alkol tarih boyunca farklı amaçlarla kullanılmış olsa da intoksikasyona neden olabilen, kötüye kullanım potansiyeli taşıyan ve tarih boyunca da bağımlılığa neden olmuş bir maddedir (6). Bu bağlamda sıkça ilgi odağı olmuştur. Alkol daha önce ifade edildiği üzere, oldukça uzun bir geçmişe sahip olduğundan bağımlıı̆ııın da uzun bir geçmişe sahip olması beklenebilir. Ancak alkol üretiminin geçmişe kıyasla ortaçağdan itibaren arttığı düşünüldüğünde ve bağımlıı̆̆ın kısmen de olsa doz bağımlı yapısı göz önünde bulundurulduğunda bağımlılığa tutulan birey sayısının zaman içerisinde arttığı öne sürülebilir. Çünkü düşük miktarlarda alınan alkolün olumsuz sonuçlara yol açma olasıı̆ı̆ı bazı istisnai durumlar dışında yok denecek kadar azdır. Ayrıca çağlar boyunca alkole ilişkin olumlu bir düşünce olagelmiş, geleneksel tıp pratiği içinde olumlu amaçlarla kullanılmıştır. Hatta modern anlamda enfeksiyon ve enfeksiyonla mücadele fikrinin olmadığı dönemlerde kontamine suların yarattığı sorunlar göz önüne alınarak sudan daha iyi bir içecek olduğu bile düşünülmüştür (23). Bugün de alkol dezenfeksiyon gibi amaçlarla tıbbi kullanımda yer almaktadır (10).

Ancak olumlu kullanım örneklerine rağmen zaman zaman alkol yasaklanmış ya da cezalandırılma sebebi olmuştur. Platon (M.Ö. 429-347) ve Plinius Secundus (M.S. 24-79) gibi önemli isimler eserlerinde doğrudan alkolün yasaklanmasını ifade etmemiş olsalar bile içme konusunda çeşitli kısıtlamalar önermişlerdir (23). Plinius Secundus alkolün seyreltilerek içilmesini önermiş̧ir (24). Genel olarak Antik Yunan'da alkole ilişkin sorunların bilinmekle birlikte ayrıntılı gözlenmediği ve alkolün tedavide sıkça kullanıldığı, ancak Antik Hint'de Caraka Samhita gibi eserlerden yola çıklarak, alkole ilişkin intoksikasyon ve inhibisyon gibi tabloların iyi tanımlanmış olduğu, fakat alkol tüketimine de olumsuz bir anlam yüklenmediği belirtilmiştir (25).

Roma döneminde alkolle ilişkili sarhoşluk gibi sorunlarla sık karşılaşılmış ve Romalılar sarhoşluğu engellediğini düşünerek lahana tüketimini önermişlerdir (26). Roma'nın yıkılması ve Hıristiyanlığın yayılması ile birlikte alkol tüketimi yasaklanmamış ve şarap kutsal bir konumda kalmış, ancak sarhoşluk ve aşırı tüketim genel olarak kınanmıştır. Kilise'nin şarap konusundaki tutumu ise alkolün tıbbi amaçlı kullanımını pekiştirmiştir. Ortaçağ boyunca alkol tüketiminin görece az olduğu söylenebilir $(4,16,18)$.

Alkolün tıbbi kullanımı olumlu anlama sahip olmakla birlikte alkol tüketimine ilişkin sorunların tıbben önem kazanması daha yakın tarihlidir. Tarih boyunca alkol ya da diğer maddelerle ilgili sorunların ilgi odağı olduğu düşünülse de, ciddi anlamdaki dönüşümlerin XIX. yüzyIlda gerçekleştiğini söylemek mümkündür. Bu yüzyılda bağımlılı̆a ilişkin çeşitli modeller öne sürülmüş, çok sayıda terimsel ifade kullanılmıştır. "Dipsomania", "narcomania" ve "alkolizm" bu dönem öne çוkan önemli kavramlar olarak değerlendirilebilir. 
Ayrıca bu yüzyılda etiyolojiye yönelik olarak öne çıkan görüş, alkole ilişkin yaşanan sorunların sinir sistemine dayalı olarak belli insanlarda ortaya çıktığı şeklinde olmuştur (27). Bu türden anlayışlara paralel biçimde öjenik hareketler ve toplumsal baskıda da artış olduğu ifade edilmektedir. Yine aynı yüzyılın önemli bir özelliğini, alkol içimini kesmeye ya da önlemeye yönelik hareketlerin ortaya çıkması oluşturur. Bu hareketlerin temel ortak noktalarından biri, alkole ilişkin sorunu bireye indirgeyen ve onlara karşı olumsuz bir algının oluşmasını sağlayan öjenik temelli hareketlerin aksine, onu alkole veya alınan maddeye odaklanarak ele almış olmalarıdır (27). Dolayısıyla alkole ilişkin sorunların tedavisine ilişkin kavramsallaştırmamızın genel olarak XIX. yüzyıla dayandığını söylemek mümkündür.

Alkolizm ve bağımlılık kavramları da benzer şekilde iki yüzyıldan daha kısa bir süredir tanısal olarak kullanılmaktadır. Addiction her ne kadar günümüzde bağımlılık ve tekrar eden biçimde bir madde ya da alkol almak anlamında kullanılsa da, aslında tanımlayıcı bir terim olmaktan çok açıklayıcı bir terim olduğu ifade edilmektedir. Şöyle ki; kökeni Roma'ya dayanan bu sözcüğün aslında "ödenmemiş borçlara karşlık olarak köleleştirmek" ile ilgili olarak kullanıldığı ifade edilmiştir. Tıbbi anlamda teknik bir terim olarak kullanılması ile daha çok davranışsal zorlantıları ifade edecek bir anlama kaymıştır (27). Alkolizm ve alkol bağımılı̆̆ı da aynı bağlamlarda kullanıımıştır ve tanı sınıflamalarında aynı anlama gönderme yapmıştır. Son sınıflamalarda ise bağımlıık terimi terk edilerek yerine, kullanım bozukluğu tercih edilmiştir (3). Buna rağmen bağımlılık ifadesinin daha yaygın ve kabul görmüş bir kullanıma sahip olduğu söylenebilir.

Felsefeciler de bağımlılık olgusunu zaman zaman tartıșma konusu etmişlerdir. Bu bağlamda temel tartışma alanlarının başında; akıllı karar vericilerin nası olup da kendilerine zarar vereceğini bildikleri bir eylemi bu bilgiye rağmen seçtikleri konusu gelmektedir (27).

Son 200 yıl içerisinde batılı ülkelerdeki gelişmelere rağmen bağımlılık alanında kapsamlı çalışma ve uzmanlaşma hareketleri açısından Amerika Birleşik Devletleri'nin daha etkin bir rol oynadığı bilinmektedir. Alkolizm teriminin ortaya çıkmasında Dr. Benjamin Rush gibi kolonyal dönem Amerikan hekimlerinin etkin olduğu düşünülmektedir. Benjamin Rush özellikle alkol ile ilişkili sarhoşluğu tıbbi bir anlamda değerlendirerek alkolizme öncül bir terim gibi açıklamaya çalışmıştır (5).

1849 ylında alkol önleme hareketlerine de önemli ölçüde destek veren İsveçli hekim Magnus Huss ilk defa alkolizm terimini kullanmıştır. Magnus Huss bu terimi; bir hastalık anlamında ve uzun süre yüksek miktarda alkol tüketimine gönderme yapacak şekilde kullanmıştır (28). Amerika Birleşik Devletlerinde alkolizme yönelik olarak hizmet veren The American Association for the Cure of Inebriety 1870 yllında; Ingiltere'de benzer amaçla hizmet veren British Society for the Study of Inebriety ise 1874 tarihinde kurulmuştur (27).

Yine alkol ile mücadelenin toplum temelli ayağı ile tıp alanındaki çabalar Amerika'da önemli ölçüde etkileşim içinde yer almıştır. Doktorların alkol konusuna ilişkin endişeleri toplumu etkilemiş ve artan toplumsal duyarlıık doktorların çabalarına olumlu katkıda bulunmuştur. Dolayısıyla karşılıkı bir etkileşim oluşmuştur. Çoğunlukla ahlaki bir sorun olarak değerlendirilen alkol ile ilişkili sorunlar, The American Association for the Cure of Inebriety adlı organizasyonda yer alan Willard Parker ve Joseph Parrish gibi hekimlerin çabalarıyla tıbbi ve çözümlenebilir bir ruhsal rahatsızlık olarak ele alınmaya başlanmıştır. Bu oluşum aracılığıyla toplum temelli alkol içmeme ya da engelleme hareketlerinden farkı biçimde bilimsel girişimler ve toplantılar düzenlenmiştir. Ancak alkolizm ve bağımlı̆̆g bilimsel bir yöntemle bakmaya çalışan bu girişimin çabaları devletin daha sert önlemleri sebebiyle tam olarak olgunlaşamadan bitmiştir. Çünkü üretim ve tüketime yönelik sert önlemler bu alanda yapılan çalışmaların sonlandırılmasına neden olmuştur (5).

Alkole ilişkin sorunların algılanmasında temelde iki ana iddia ortaya atımıştır. Bunlar, alkole ilişkin sorunlar ve çözümlerin bireysel farklılıklara dayandığı görüşü ile alkole ilişkin sorunların herkes için potansiyel olarak ortaya çıkabileceği şeklindeki görüşleridir. Yapısal farklılıklara dayalı yaklaşım özellikle Adsız Alkolikler ve sonrasındaki hareketlerin asıl dayanak noktasını oluşturmuştur. Evrensel olarak herkes için potansiyel risk düşüncesi ise daha çok toplum sağı̆ğı yaklaşımları tarafından benimsenmiştir (27).

Sonuçta alkolün tarih boyunca tüketiminde artış ve azalışlar olmuş, buna paralel olarak alkole ilişkin sorunlar da artma ve azalma şeklinde hareketlilik göstermiştir. XIX. yüzyllın başlarında oldukça yüksek 
seviyelere ulaşan alkol üretim ve tüketiminin aynı yüzyıl içinde azalma eğilimi gösterdiği, bunun da aşırı alkol tüketiminin çalışan verimliliğini düşürmesi ve bunun önüne geçmek amacıyla yürütülen faaliyetlere bağlı olduğu iddia edilmekle birlikte bunun tek açıklayıcı neden olmadığı ifade edilmiştir. İkinci Dünya Savaşı sonrasında alkol tüketiminde yine bir artış yaşanmış olduğu, ancak 1970'lerden itibaren bağımlılığın tıbbi anlamda önemli bir çalışma alanı olması ile birlikte azalma eğilimine girdiğine değinilmiş̧tir. Ayrıca alkol tüketimindeki dalgalanmaların en az dışsal nedenler kadar, alkolün tüketildiği toplumun mikro düzeyde içsel nedenlerine de bağlı olabileceği değerlendirilmiştir. Örneğin sosyal etkileşimde önemli bir araç olması, belirli toplumlar özelinde önemli bir etken olarak ileri sürülebilir (29). Alkol tüketim miktarları değişim gösterdikçe devlet müdahaleleri de gelmiştir. Özellikle tüketimdeki azalma dönemlerinde yasal kısıtlamalar gevşetilmiştir (27).

Genel olarak alkolün kullanımına bakıldığında, sosyal içicilikten başlayarak bağımlı̆̆g uzanan bir spektrum içerisinde olumlu ve olumsuz özellikleri barındıran bir tarihe sahip olduğu görülmektedir. Buna rağmen psikiyatri ve alkol tarihi konusundaki çalışmalar kısıtı olduğundan ayrıntılı çalışmalara intiyaç duyulduğundan bahsedilmektedir (27). Bu çalışmanın bundan sonraki kısmında alkol bağımlılı̆ı ile mücadelede tıbbi alanın tam içinde yer almayan, ancak tam olarak dışında da olmayan, fakat alkole ilişkin bilgi ve tarihimizi aynı zamanda tedavi yaklaşımlarını etkilemiş olan Adsı Alkolikler konu edilerek bu eksiklik farkı bir çerçeveden ele alınmıştır.

\section{Günümüzde Alkol Bağımlılığı ve Tedavisi}

Günümüzde önemli bir problem olarak değerlendirilen alkol bağımlılığına ilişkin sorunlar, aynı zamanda birçok tıbbi ve ruhsal sorunla da yakından ilişkili ve iç içe geçmiş durumda olduğundan, sağlığın önemli bir ilgi alanı konumundadır. İntihar, bağımlılık yapıcı ek madde kullanımı ve depresyon gibi başka sorunların yanı sıra kanser gibi rahatsızıkların da alkol ile sıkı ilişkisi vardır (30-32). Aşırı olmayan miktarlarda alkol tüketiminin özellikle kardiyovasküler hastalıklar açısından olumlu etkilere sahip olabileceği kaydedilmekle birlikte, bunun alkolden çok alkolün içerisinde yer aldığı ürünün diğer özelliklerinden (antioksidan vs.) kaynaklanabileceği vurgulanmaktadır (33). Dünya Sağlık Örgütü’nün (WHO) 2014 yılı verilerine göre tüm dünyada meydana gelen ölümlerin \%5,9'u alkol ile ilişkilendirilmiştir (34). Alkolün doğrudan kendisine yönelik ilgi alanının merkezini ise bağımlılık ve tedavisi oluşturmaktadır.

Günümüzde bağımlılık, genel olarak bağımlılı̆a neden olan maddelerin beyin üzerinde yineleyen farmakolojik etkileri zemininde oluşan ve tekrarlarla gidebilen bir sorun alanı olarak görülmektedir. Ayrıca bağımlılık tek bir nedene bağlanmayan ve aniden ortaya çıkması beklenmeyen bir süreç olarak değerlendirilmektedir. Madde kullanımı dışında bazı davranışsal bağımlılıklar da mevcuttur (35). Özellikle limbik sistemde meydana gelen dopaminerjik aktivasyon ve buna bağlı olarak diğer nörotransmitter sistemlerinin de işe karışması alınan maddenin kendi alımına olan isteği zaman içerisinde güçlendirmektedir. Bunun sonucu olarak beyin adaptasyon gerçekleştirerek yapısal bir dönüşüme uğramaktadır. Bu maddeler aracılığıya oluşan dönüşümün beynin normal sirkülasyonunda bir farklıaşmaya neden olarak kişinin davranışları üzerindeki kontrolünü etkilediği iddia edilmektedir. Özellikle ödül sistemi, motivasyon ve yürütücü işlevler, engelleme gücü ve bellek gibi alanlar etkilenmektedir. Sonuçta kendini kontrol edebilme yetisi zarar görebilmektedir (36).

Bağımlııkla ilişkili sorunların klinik görünümünün ana belirteçlerini; alınan maddenin bireyin başlangıçta istediği miktar ve süreleri aşması, yineleyen bir biçimde maddenin istenir ve aranır olmasının yanı sıra kesme ya da azaltma çabalarındaki başarısızlık deneyimleri, zaman içinde bireysel ve sosyal yaşantılarda zorluklar ve inmaller meydana getirmesi, maddeye zamanla tolerans gelişmesi ile birlikte alınmadığı zamanlarda çekilme belirtisi görülmesi ve bunu gidermeye yönelik tekrar maddeye başvurma oluşturmaktadır (7).

Özel olarak alkol bağımlılı̆ı değerlendirildiğinde ise bağımlılı̆a ilişkin söylemin alkol tüketimi için özelleştirildiği görülmektedir. Bu noktada üzerinde durulması gereken bir gelişme, günümüze kadar tanı sınıflamasında alkol bağımlılığı ya da bağımlılık olarak geçen tanısal ifadenin son tanı sınıflama 
sistemlerinde (ICD ve DSM) "kullanım bozukluğu" olarak değiştirilmiş olmasıdır (3). Bu değişikliğe gidişin nedeni olarak bağımlılık ifadesine ilişkin olumsuz algının azaltılması, daha önce kullanım bozukluğu ve bağımlılık ifadelerinin aynı anda farklı tanılar olarak yer almasının yarattığı karışıklık ve bilimsel olarak yeterince güçlü olmayan tanısal ayrımın giderilme çabası gösterilmişstir. Yine de klinik kullanımda bağımlıık ifadesinin özellikle daha ağır bağımlılık olguları için kullanımının uygun olabileceğine değinilmiştir $(7,37)$. Bu değişiklikle, kullanım bozukluğu ve bağımlıık arasında iç içe geçmiş ve ciddi sonuçları olan durumların gerçekte bir sürecin farklı aşamaları olarak değerlendirmesinin sağlık açısından olumlu sonuçlanacağı düşünülmüştür (37).

Sonuç olarak alkol bağımlılı̆ı günümüz için önemli bir sağlık sorunu olarak varlığını sürdürmektedir ve bu durum Türkiye için de geçerlidir. Örneğin aralarında İsveç, Fransa ve ABD'nin yer aldığı ülkelerde yetişkin yaş grupları için \%10-15'lere yaklaşan alkol bağımlılığı oranları görülmektedir. Türkiye'de oranlar görece az olmakla birlikte artış eğlimindedir (7). Yakın tarihli verilerde alkol kullanım bozukluğu oranı \%2,5 ve alkol bağımlılı̆ı oranı ise \%0,8 olarak bildirilmektedir (38). Kullanım bozukluğu ve bağımlılık sınıflandırmada tek başııkta toplandığından bu oranın artmış olabileceği düşünülebilir.

Alkol bağımlılığı tanısı günümüzde klinik olarak konulmaktadır (7,35). Alkol bağımlılı̆ında laboratuar bulguları kesin sonuç veren belirteçler olmamakla birlikte klinik belirti ve özellikleri destekleyebildikleri gibi izlemde de kullanılmaktadırlar (39).

Alkol bağımlıı̆ı ya da kullanım bozukluğu, süreğen bir hastalık olması ve tekrarlarla seyretmesi nedeniyle tedavisi çok boyutlu bir yapıya sahiptir. Alkolün terk edilmesini takiben ortaya çıkan kesilme aşaması genellikle yakın bir izlemi, sıvı ve vitamin desteklerini içeren bir yaklaşımı gerektirir. Bu aşamadaki asıl amaç oluşabilecek hayati riskleri, konvülziyonları ve metabolik sorunları önlemektir $(7,8)$. Tedavinin diğer aşamasını ilaçların ve psikososyal yaklaşım ve terapi yöntemlerinin kullanıldığı alkol isteğini azaltma ve uzun süreçteki yinelemelere karşı koruyucu önlemler oluşturur (7). Çünkü alkol bağımlılığı hastalığın doğasından kaynaklanan nedenlerle nüksün sıkça görüldügüü bir durumdur (8). Koruyucu ve önleyici tedavi basamağının önemli bir parçasını hastaların, alkol kesme ve ilaç tedavisinden sonra izlemde kalmalarının ve bireylerin kendine yardım gruplarına katıımının sağlanması oluşturmaktadır. Bu sayede hastane sonrası dönemde nüksün en aza indirilmesi amaçlanır (40).

Alkol bağımlılı̆ıyla mücadele konusunda en önemli grupların başında bir kendine yardım grubu olan Adsız Alkolikler gelmektedir. On iki basamak programı şeklinde kurulmuş olan bu yapı, hastalar tarafından yürütülen ve alkol içmemeye yönelik becerilerin geliştirildiği bir kurguya sahiptir $(7,8)$. Genel olarak Adsız Alkoliklerin yürüttüğü programların alkol bağımlıarının alkolden uzak durma konusundaki motivasyonlarını olumlu etkilediği düşünülmektedir $(7,40)$.

\section{Destek Grupları ve Kendine Yardım Grupları Kavramları}

Destek grupları, ortak bir şeye sahip olan ve bir şeyleri çözmek ya da bir görevi yürütmek için ortaklaşa bir çaba sergileyen insanların oluşturduğu topluluklardır. Genellikle üstlendikleri görev ya da çözümden kastedilen ise; bir konudaki bilgiyi genişletmek, bir amacı başarmak, bireysel gelişime katkıda bulunmak ya da grup üyelerinin sorunlarını ve rahatsızlıklarını iyileştirmektir. Bazı yayınlarda kendine yardım grupları, destek gruplarının içinde konumlandırımakta ve destek gruplarının daha özelleşmiş bir alt grubu olduğuna vurgu yapılmaktadır (41). Ancak genel olarak destek ve yardım gruplarının aynı olmadığı birtakım farklııkların mevcut olduğu ifade edilmektedir $(41,42)$.

Kendine destek ve kendine yardım grupları arasındaki ayrım; bu gruplar içerisinde bir profesyonelin varlığı, grubun büyüklüğü, grubun değişme ve dönüşme kapasitesi ve boyutları, programın felsefesi ve kompleks oluşu gibi özelliklere dayanır (42). Destek grupları ile kendine yardım grupları arasındaki en önemli ayırt edici, ikincisinde değişimin amaçlanmış olmasıdır. Kendine yardım grupları, destek grupları ve psikoterapi gruplarının anlamları yönünden kafa karışıkıkları yaşanmaktadır. İkisinin de değişimi amaçladığı bilinen kendine yardım grupları ile psikoterapi arasındaki farkı, psikoterapi grubunda profesyonel bir terapistin grupta yer alması ve grubun yürütülmesinde ana belirleyici olması oluşturur. Kendine yardım gruplarında 
ise profesyonel bir yürütücü genellikle yer almaz. Profesyoneller kendine yardım gruplarına danışmanlık, üye yönlendirme ya da davetli olarak destek verebilirler ancak psikoterapideki gibi fonksiyonlar üstlenmezler (42).

\section{Destek Grupları}

Yaygın bir sorun için duygusal destek ve bilgilendirme amacıyla toplanan gruplardır. Genellikle bu toplantılar profesyoneller, sosyal platformlar ya da resmî kurumlar tarafından düzenlenir ya da desteklenir. Davranışsal ya da sosyal dönüşüm birincil amaç değildir ve katılım kriterleri organizatörler tarafından belirlenir (42).

\section{Kendine Yardım Grupları}

Bu gruplar, grubun tüm üyeleri tarafından paylaşılan bir soruna ilişkin, destek, eğitim ve kendini değiştirmek konusunda karşılıklı yardım ilişkisine dayanır (42). Sosyal ya da bireysel dönüşümler sağlanmaya çalışlırken, çeşitli ideolojik ve düşünsel yöntemlere başvururlar. Grubun lideri gruptan birisidir, gruba katılmak gönüllülük esasına dayalıdır ve herhangi bir ücret ödenmez. Profesyoneller grubun bir üyesi olmadıkça, nadiren grup etkinliklerinde aktif rol alırlar. Gruplar tarafından yapılan toplantılar yapılandırımıştır ve mevcut sorun alanlarına ilişkin yardım sağlanması amacını taşır. Yerel gruplar, ülke çapındaki ana merkeze kıyasla görece özerk yapıya sahiptirler (42). Karşılıklılık ilkesiyle iş gören yardım gruplarında grubun temel işlev alanlarını sakatıklar, bağımlıık, istismar, kötüye kullanım, ölüm ve diğer önemli yaşamsal sorunlar konusunda bireylere yardım sağlamak oluşturmaktadır. Resmî nitelikte olmamaları, katılımın tamamen gönüllülük esasına dayanması, kâr amacı güdülmemesi, anonimlik ve bireyin gizliliğinin önemsenmesi yardım gruplarının diğer önemli özelliklerindendir (41).

Yardım grupları Batı kültüründe önemli bir yer edinmişlerdir. Bu bağlamda bağımlııkla ilgili sorunlara yönelik çok sayıda grup ortaya çıkmıştır. Bu gruplar sorunun mutlak çözümünü sağlamıyor olsalar da özellikle alkol bağımlılığı ve diğer maddeler ile ilgili yaşanan sorunlar konusunda önemli etkinliğe sahiptirler. Dolayısıyla tedavi sürecinde tedavinin önemli bir parçası olarak seçenekler içine dahil edilmektedirler (43). Örneğin ABD'de özellikle bağımlıık gibi sorunlar için psikiyatrik yardımdan daha fazla yardım gruplarına başvurulduğu iddia edilmektedir (41).

Bağımlıık ile ilgilenen tıp alanı, ilaç destekli tedavilere ek olarak özellikle arkadaşlık gruplarınca uygulanan tedavi yaklaşımlarından hem ilham hem de destek almıştır. Bu gruplardan en ünlüsünün AA olduğu söylenebilir. 1935 yllında Bill Wilson ve Dr. Bob Smith tarafından kurulan bu grup ya da program kısa sürede ilgi odağı haline gelmiştir. En önemli özelliklerinden birisi cinsiyet, ırk, dil, din ya da sosyoekonomik düzey farkı gözetmeksizin herkese kucak açmış olmasıdır. Bu programa dahil olmanın tek koşulunu "içmeyi durdurmak konusunda samimi bir niyet” oluşturmuştur. 1940'lardan başlayarak ve özellikle 1960'lardan sonra tıbbi çevrelerce de önemli ölçüde taktir kazanmış bu oluşum, zaman içinde tedavi sonrası desteğin önemli bir parçası haline gelmiştir (44).

Günümüzde de önemli bir halk sağlığı problemi olarak görülen alkol ve madde bağımlılığı gibi sorunlara yaklaşım ve çözümde kendine yardım grupları önemli bir kaynak işlevi görmektedir (45). AA ve sonrasında kurulmuş olan kendine yardım gruplarının büyük kısmı on iki basamak organizasyonları olarak da tanımlanırlar. On iki basamak bu grupların iyileşmek için dayandıkları felsefeye gönderme yapar. Bu bağlamda öncelikle bağımlıık bir hastalık olarak değerlendirilir. Bağımlılığın süreğenliğine vurgu yapılırken, bireysel olgunlaşma ve spiritüel gelişim önemsenir, ayrıca ben-merkezcilik olumsuzlanır. Bu felsefeyi kendilerine dayanak olarak alan AA için önemli konulardan birisi de diğer bağımlılara yardım etmektir (45). Kendine yardım gruplarının dünyada yayılmasında ve yeni program ve grupların oluşmasında AA'nın ve felsefelerinin önemli etkisi olmuştur (40). Zaman içinde AA dışında ve on iki basamak organizasyonunu kullanmayan alternatif oluşumlar ile daha seküler ağırlıklı oluşumlar da kurulmuştur. Örneğin alkol etkisinde olmamak için seküler organizasyonlar ya da kendini koruma grupları bunlardan bazılarıdır (46). Günümüzde AA dışında Adsız Narkotikler, alkol sorunu yaşayan bireylerin yakınlarının oluşturduğu Al-anon (Alkolik Yakınları) gibi bağımılı̆ğa yönelik çok sayıda grup dışında, diyabet, Alzheimer hastalığı gibi farklı kronik hastalıklar için kurulmuş gruplar da mevcuttur (45). 


\section{Adsız Alkolikler'den Önce ve Sonra}

Amerika Birleşik Devletleri'nin kurulmasından itibaren alkol tüketiminde artış yaşanmıştır. Buna bağlı olarak da pek çok alkol karşıtı hareket ortaya çıkmışıı. Bu gruplar özellikle alkol tüketiminin artışının, artan suç ve şiddet olayları ile birlikte toplumsal ahlakın bozulmasılyla ilişkili olduğunu iddia etmişlerdir. Bu sürecin yaşanmasında öne sürülen önemli nedenlerden bazılarını, Amerika'ya doğru yaşanan yoğun göç dalgası ve toplumsal sorunların artmış olması olușturur (5). Özellikle XIX. yüzyıl sonu ile XX. yüzyıl bașında alkol tüketilen alanlarda artış olması ve bu alanların çalışanlarca yoğun bir şekilde kullanılması ile verimliliğin olumsuz etkilenmesi, bu nedenle de işverenlerin alkol tüketimini hoş karşılamamaları dile getirilmiştir. Bazı işverenlerin alkol tüketenlere iş vermediği bilinmektedir (5). Protestan Kilisesinin başını çektiği alkol karşıı hareketler önemli bir baskı unsuruna dönüşmüş ve 1920'de alkolün yasaklanması sonucunu doğurmuştur (5).

1920 ile 1933 arasında Amerika Birleşik Devletleri'nde tıbbi ve dini ritüeller dışında kullanılan alkolün satılması, üretilmesi ve taşınması yasaklanmıştır. Ancak bireysel tüketim ve üretim konusunda bir kısıtlama getirilmemiştir. Bu madde dönemin Amerikan Başkanı olan Woodrow Wilson tarafından veto edilmiş olsa da Temsilciler Meclisi ve Amerikan Senatosu tarafından onaylanmıştır. 1919'da görüşülüp karara bağlanan yasa 1920 ylında yürürlüğe girmiştir. Volstead kanunu olarak bilinen 18. madde ile getirilen yasak 1933 yılında 21. madde ile bütünüyle yürürlükten kaldııımıştır (47). Yasal kısıllama sürecinde gelir vergilerinde yaşanan önemli düşüş ve illegal yollar ile alkol teminini sağlayan örgüt ve suçların artmış olması yasanın kaldırımasında önemli rol oynamıştır (48).

Bağımlı̆̆ğın tıbbın gündemine girmesi XVIII. yüzyılın sonlarına dayanmaktadır. Özellikle Dr. Benjamin Rush'un alkol sorununu bir hastalık olarak görmesi ve bu soruna sahip insanların da tedavi almaları gerektiği üzerinde durması oldukça etkili olmuştur. Bu dönemden itibaren çeşitli tıbbi çalışma ve tezler hazırlanmıştır. 1870'lere gelindiğinde ise bağımlıı̆ın tıbbi pratik içinde bir uzmanlık alanı olarak görülmeye başlandığı görülmektedir. 1900'lerin başına kadar pek çok hekim bağımlılık konusunda çalışmalar yapmış ve gerek muayenehanelerinde gerekse hastanelerde tedavi çabaları sürdürülmüştür. Ancak tıp alanı dışındaki etkenler sebebiyle 1900'lerin başlarında bağımlılık tıbbı güçç kaybetmiştir. Özellikle ekonomik sorunlar ve tedavi başarısına yönelik karamsar bakış ile birlikte tedavi kurumları kapanmış, alkol ve uyuşturucu gibi konularda tedavi yerine yasaklamaların etkili olacağı düşünülmüştür. Tüm bu nedenler bu alandaki bilimsel çalışmaların aksamasına ve destek görmemesine sebep olmuştur (49). Bu durum yasak yılları olarak bilinen 1920 ile 1933 arasında da devam etmiştir. Bu süreç alkol sorununun kamuoyu desteği ile tıp biliminden alınarak hukuk alanına verildiği bir dönem olarak tarif edilmiştir.

Ancak 1933'ten sonra bağımlılık konusu tekrar önemli bir başlık olarak gündeme gelmiş ve "alkolizm" bir hastalık olarak tanımlanarak tanısal kategorilerde yer almıştır. Bu gelişmelerde Adsı Alkolikler'in önemli katkısı olduğu ifade edilmektedir $(5,49)$. 1935'ten sonraki dönem bağımlılık tedavisinin yeniden doğuşu olarak adlandırımaktadır. 1937 yılında alkol sorunlarının bilimsel olarak araştıııması amacıyla ulusal bir komisyon kurulmuştur. 1942 ylında Yale Alkol Çalışmaları Merkezi oluşturulmuştur. 1944'te ise Ulusal Alkolizm Eğitim Komitesi kurulmuştur. Bu dönemde alkolizme yönelik tedavinin ana eksenini uygun hospitalizasyon ve bakım ile birlikte arındırma tedavisi ile bunu takiben alkol sorununa yönelik rehabilitasyonun sürdürülmesi oluşturmuştur. Yine bu dönemde çeşitli terapi yöntemleri geliştirilmeye çalışılmışır. Hastaneler AA'ya toplantılar için bölümler tahsis etmiş ve önemli ölçüde karşılıklı bir etkileşim yaşanarak terapötik yöntemler geliştirilmiş̧ir. Özellikle Minnesota'da Willmar ve Hazelden gibi merkezlerde arındırma tedavisi sonrasındaki ayaktan hastalar için önemli çalışmalar yapmışlardır. Bu dönemin en önemli özelliği alkolizmin tedavi edilebilir bir hastalık olarak kabul edilmesidir (49).

\section{Adsız Alkolikler (AA)}

Bağımlıık ile ilgili sorun yaşayan bireyler öncelikle tıp profesyonellerinden, hastanelerden, psikiyatristlerden yardım almaktadırlar ve genellikle bu gereksinimleri daha çok akut dönemde olmaktadır. Bu bireyler daha 
sonra da yardım arayışlarını sürdürmektedirler. Bu bağlamda da dini liderler, güvenilir arkadaşlar, aile üyeleri ve iş arkadaşlarının yardım ve tavsiyelerinden yararlanmaktadıllar. Her ne kadar profesyonellerden yardım alınıyor olsa da çok sayıda bireyin rehberlik almak, bilgilenmek, destek görmek ve pratik ve işe yarar tavsiyeler almak için kendine yardım gruplarına başvurduğu bilinmektedir (50).

Bağımlılık, önemli bir sağlık ve toplumsal sorun olarak ortaya çıktığından onunla ilişkili kendine yardım grupları da yaygınlaşmıştır. Damgalanmama isteği bu türden grupların yaygınlaşma nedenlerinden olmuştur. Ayrıca zaman zaman sağlık profesyonellerinin bu türden hastalara karşı olumsuz tutumlarının da bu grupların ilgi odağı olmasını tetiklemiş olabileceği düşünülmektedir. Bireylerin hastalığın süreğenliğine bağı olarak sadece bir sağlık kuruluşuna bağlı kalmayı bağımlılıkla mücadelede yeterli görmüyor olabilecekleri ifade edilmektedir (50).

AA neredeyse tüm dünyaya yayılmıştır ve en çok sayıda üyeye sahip olan kendine yardım grubudur (45). Yukarıda belirtildiği gibi AA tarihsel olarak 1935 ylında kurulmuştur (51). Ancak bir sosyal fenomenin tarihsel gelişimini anlamak için onun öncesine de bakmak gerekir. Özellikle XX. yüzyllın ilk çeyreği yarıdinsel görünüme sahip Lutheriterian hareketlerin yükseldiği ve yayıldığı bir dönemdir. Alkol sorunu yaşayan bireylerin bu türden hareketlere yardım aramak amacıyla başvurdukları bilinmektedir (52). Bu bağlamda Oxford Grubu alkol sorunu ile mücadele konusunda çabalara yer vermiş önemli aktörlerdendir. Bu grupta alkol sorunu yaşayan ve onunla mücadele eden bireyler yer almışıı. Bunlardan birisi ünlü psikanalist Carl Gustav Jung'un da hastası olan Rowland Hazard'dır. Rowland Hazard, Jung'un alkol sorununu çözmede ruhsal bir dönüşüm ve gelişimin kendisine yardım edeceği söyleminden yola çıkarak grupta bu konuda bir etki oluşturmuş ve zaman içinde Adsı Alkolikler'in kurulmasında da düşünsel anlamda etkili olmuştur $(50,53)$. Oxford Grubu'ndan arkadaşı olan Edwin Thatcher, Rowland Hazard'ın görüşlerinden etkilenmiştir. Thatcher aracıı̆ğıla bu fikirler 1934 ylında daha sonra AA'nın iki kurucusundan birisi olacak olan ve alkol sorunu yaşayan William Grift Wilson'a (Bill W.) ulaşmıştır (50).

Illk anda Oxford Grubu'nun ve Jung'un bakışından pek etkilenmemiş olan Wilson daha sonra, alkole bağlı acil bir klinik tablo sırasında yaşadığı spiritüel deneyimin ardından bu fikirlere önem vermeye başlamıştır. Bu süreçte Wilson, Thatcher'dan, Hazard ve dolayısıyla Jung'dan ve kendisini destekleyen hekimi William Silkworth'dan yararlanarak sadece tıbbi süreçlere bağlı kalmadan önemli ölçüde spiritüel yaklaşımlardan da faydalanarak alkol sorunuyla baş etmeye çalışmıştır (50). Başlangıçta Oxford Grubu'ndan etkilenmiş olan Wilson (Bill W.), daha sonra bu gruptan ayrılmıştır. 1935 yılında bir seyahat sırasında ayıklık döneminde olduğu halde sık sık alkol alma isteği duymuştur. Bu durumla baş etmek için birkaç defa rahiplerle görüşmeye çabalamış, ancak sonuç alamamıştır. Sonrasında kendisi gibi alkol sorunu yaşayan bir cerrah olan Dr. Robert Holbrook Smith (Dr. Bob Smith) ile görüşmüştür. Bu görüşme sonrasında alkol sorunu yaşayanların bu sorunlarını aşmada bir başka alkolikten destek alabilecekleri fikrini geliştirmişlerdir $(50,54)$. Bu görüşme günümüzde Adsız Alkoliklerin ilk toplantısı olarak bilinmektedir (50).

Illk dönem gerçekleştirilen toplantıların önemli bir kısmı Oxford Grubu'nun desteği alınarak gerçekleştirilmiştir. Ancak zaman içinde Oxford Grubu'nun katı dinsel yaklaşımları grup üyelerini olumsuz etkilemiştir. Oxford Grubu'nun katı ve insanüstü beklentileri üyelerde çökkünlük ve depresyona neden olmuştur. Bu süreçte alkol sorunu yaşayan bireylerin intiyaçlarını gözeten daha esnek ve uygulanabilir bir model geliştirilmeye çalışılmıştır. Böylece 1939 yılına gelindiğinde AA kendi kitapları olan Adsız Alkolikler ya da AA arasında "Büyük Kitap" olarak bilinen kitabı basmışlardır. Bu kitabın basımından sonra AA'nın tanınırlı̆ında bir artış olmuş, aynı zamanda toplum içinde de alkolizm konusunda farkındalık meydana gelmiştir (50).

AA 1940'lar boyunca oldukça hızlı bir şekilde büyüme kaydetmiştir. Aynı yıllar AA grubunun üyelerinin yöntem ve felsefelerini de derinleştirdikleri bir dönemdir. Başlangıçta Oxford Grubu, William James, Carl Gustav Jung gibi dış kaynaklardan etkilenmiş olsalar da zaman içinde felsefe ve yaklaşımlarındaki asıl belirleyen alkol sorunu yaşayan üyelerin iyileşme deneyimleri olmuştur (50). Grubun gelişimi ve felsefesinin dönüşümünde grup içi tartışma ve fikir alışverişlerinin önemli etkisi olmuştur. 1950'ye gelindiğinde AA'nın ikinci önemli kitabı olan "On İki Basamak ve On İki Gelenek" yayımlanmıştır (50). On İki Basamak, temelde AA grubunun ilk üyelerinin bağımlııkla mücadelelerinde kendilerini başarıya götüren deneyimlerinin bir 
sunumudur ve daha sonra diğer üyelerin de deneyimlerini paylaşmaları ile zenginleşerek gelişmiştir. On iki basamak geleneğinde, üyeler bir araya gelerek, kendi güçlü yanlarını, umutlarını ve deneyimlerini paylaşarak hem kendilerinin hem de diğer grup üyelerinin ayık kalmalarını sağlamayı amaçlarlar $(55,56)$. Ayrıca alkol sorunu yaşayan bireylerin alkolle ilgili istek ve arzularından dolayı sürekli kendilerini suçlamamaları, alkole ilişkin kontrol güçleriyle ilgili zorluk yaşamalarının doğal olduğu ve bu sebeple kendilerine merhamet göstermeleri gerekebileceği, kendilerini alkolik ya da bağımlı olarak kabul etmeleri gerektiği ve alkol almamalarının tedavi için önemli bir amaç olarak görülmesi önemli düşünsel dayanakları oluşturmaktadır. Bunlara ek olarak yaşadıkları sorunun ruhsal bir sorun olarak kabul edilmesi önemlidir (43).

ABD'de kurulmuş olan bu hareket zaman içerisinde önce Kanada, daha sonra da üyelerinin diğer ülkeleri ziyaret etmeleri sayesinde dünyaya yayılmaya başlamıştır. Merkezi New York'ta bulunan AA kuruluşundan günümüze kadar istikrarlı bir şekilde büyümeye devam etmiştir. AA'nın 2016 tahmini verilerine göre dünya genelinde 2,103,184 üye ve 100,000'den fazla grup vardır. Ancak üyeleriyle ilgili kayıt tutmadıkları ve bu verilerin tahmini olduğu bilgisine yer verilmiştir. Buna rağmen 181 ülkede faaliyet gösterildiğinin bilindiği ifadelerde yer almıştır (57).

AA tarihsel olarak gelişimini sürdürürken kendisinden ilham alınarak başka gruplar da oluşmuştur. Örneğin, Adsız Narkotikler, Adsız Kumar Bağımlıları bunlardan bazılarıdır. Madde bağımlılığı sorunuyla uğraşan Adsız Narkotikler bu gruplardan en büyüğü ve tanınır olanıdır (50). AA ulusal ve uluslararası düzeylerde kongreler de düzenlemektedirler (58).

\section{Adsız Alkoliklerin Düşünsel Dönüşümü}

On dokuzuncu yüzylın sonlarına doğru alkolizme bir hastalık olarak bakmaya ve çözüm aramaya çalışan tıbbi anlayışın XX. yüzylın başlarında toplumsal nedenlerle ardındaki desteği vitirdiği ifade edilmiştir (5). Özellikle XX. yüzylın başında alkol sorunu yaşayan pek çok kişi ayıklığa kavuşmak ya da sürdürmek için dini içerikli yapılara başvurmuştur. Bu yapılardan birisi genel olarak eklektik bir düşünsel yapıya sahip, mezhepsel farklılıkları önemsemeyen ve sade bir Hıristiyan yaşayışı öneren Oxford Grubu'dur (59). AA grubunun ilk üyeleri bir şekilde alkole ilişkin yardım arayışları sürecinde bu grup ile temas etmişlerdir. Bu kişilerin başında da AA'nın kurucuları olan Bill W. ve Dr. Bob Smith gelmektedir (52). Dolayısıyla daha önce de ifade edildiği üzere AA grubunun özellikle ilk dönemde Oxford Grubu'ndan etkilenmiş olduğu bilinmektedir. Ancak zaman içerisinde düşünsel anlamda önemli değişiklikler yaşanmıştır. 1939 yılında daha önce Oxford Grubu'nda yer almış olan Ebby Thatcher ile Bill W. arasında geçen bir görüşme grubun tutumunu önemli ölçüde etkilemiştir. Bu görüşmede Thatcher, Bill W.'ye herhangi bir dinin Tanrısına inanmak zorunda olmadığını, herkesin kendisine göre Tanrı kavramına sahip olabileceğini söylemiştir. Bu konuşma agnostik olan Bill W.'nin dikkatini çekmiştir. Böylece AA'da Tanrı kavramsallaştırması yerine her bireyin kendince anlayacağı bir "üstün güç" kavramı ortaya atılmıştır (52).

\section{Adsız Alkoliklerin Felsefesi ve Önemli Kavramları}

AA'nın daha iyi anlaşılmasının yolu on iki basamak programının anlaşılmasından geçmektedir. On iki basamak programının en temel özetini grubun logosunda görmek mümkündür (60). Bir daire içerisine yerleştirilmiş üçgen mevcuttur ve üçgenin her bir kenarı birer kavramı temsil eder (60). Bunlar, ivileşme (recovery), hizmet (service) ve birliktir (unity). Daire ise tüm kavramların birlikteliğini ve bundan doğan gücü temsil eder (61).

lyileşme; bireylerin alkol kullanmadan yaşadıkları yeni yaşam yolu anlamına gelir. Böylece alkol bağımısı alkolü kestikten sonra yeni bir yaşama adapte olmaya çalışır. Bu süreçte alkol bağımlısı toplantılara katılır, yaşanmış deneyimlere dayanan bilgiler edinir, on iki basamak üzerine çalışır, diğer üyelerle işbirliği içinde olur. Hizmet; alkol sorunu olan bireylerin birbirilerine yardım etmeleri ve iletişim içinde bulunmaları anlamına gelir ve 12. basamağı da temsil eder. Önemli olan sadece diğerlerine yardım etmek değildir; aynı zamanda bir birliktelik ve gönüllülük duygusu ile grubun çalışmasına da hizmet etmektir. Birlik ise grup içindeki arkadaşık ve birlikteliğin iyileştirici gücünü ifade eder. Bu iyileşme sadece bireylerin iyileşmesini 
değil, grubun, ülkedeki diğer grupların ve tüm sorun yaşayan insanların sorunlarının da çözülmesi amacını taşır (60).

AA'nın spiritüel karaktere sahip olduğu bilinmektedir. Ancak Tanrı inancı gibi konulara daha az yer verilirken, prensip ve pratiklerin büyük bölümünü; özgecilik, umut, merhamet, affedicilik, bencillikten kaçınma ve diğerlerine yardım oluşturur. Genel olarak AA'nın spiritüel yöntemlerinin dini temelli olmadığına da sıkça vurgu yapılmaktadır. AA kendi üyelerinin gönüllü katkıları dışında herhangi bir ekonomik desteği kabul etmemektedir. AA'da yer almanın her bir basamağı (grubun üyesi olmak, toplantılara katılmak, dinlemek, konuşmak, iletişim vs.) o gün için ve geleceğe yönelik alkol almamak için bir gerekçe oluşturur. Dolayısıyla kendileri tarafından bir yaşam yolu olarak adlandırılan bir sürecin içinde bulunurlar. Bu süreçte içmemeyi başarmış olan üyelerin destekleri, okunan materyaller, gidilen toplantılar paylaşılan deneyimler ile sürekli ve yineleyen biçimde bir yardım ve duygusal destek sağlanır (62).

AA'nın kabul edilmiş bazı avantajlarını; ücretsiz olması, kolay ulaşılabilir olması, alkolü kesmeye odaklanması ve bunu başaran ya da başarmaya çalışan bireylerden oluşan yapısı oluşturur. Ayrıca bir sigorta sistemi gerektirmiyor olması ve bireylerin damgalanma intimalini azaltması da önemli avantajlar olarak değerlendirilmektedir (52).

\section{Adsız Alkolikler ve Alkol}

AA, kendilerini ne alkol karşıtı ne de alkol destekçisi olarak tanımlarlar. Ancak ifade ettikleri gerçek şudur; alkol, çok sayıda kişi için keyif verici bir madde iken, AA üyesi olan birisi için zararlı bir maddedir. Bu nedenle başkalarını alkol konusunda engellemek söz konusu değildir. AA grubu için alkolün kendisinin bir ilgi odağı olmadığı, asıl ilgi konusunun alkol sorunu yaşayan ve onu bırakmak isteyenler olduğu özellikle vurgulanır $(63,64)$.

\section{Adsız Alkolikler ve On İki Basamak}

Davranış ve tutumları değiştirmeye yönelik on iki ifadeden oluşur ve 1939'da grubun ilk yayını olan Adsız Alkolikler isimli eserde yer almış, sonraki basımlarda da varlığını sürdürmüştür. AA'ya göre bu program sadece bireylerin alkole olan bağımlılıklarından özgürleşmelerini sağlamakla kalmayıp onlara hayatlarında uygulayabilecekleri yeni bir yöntem sunmaktadır $(52,56)$.

On iki basamağı anlatan ifadeler şu şekildedir;

1. "Alkole karşı güçsüz olduğumuzu ve yaşantımızın yönetilemez hale geldiğini kabul ettik."

2. "Sadece bizden üstün bir gücün akıl sağlığımızı geri getirebileceğine inandık".

3. "İrademizi ve hayatımızı algıladığımız anlamdaki Tanrı'ya teslim etmeye karar verdik."

4. "Geçmişimizin ahlaki bir dökümünü araştırıcı ve korkusuz bir bakışla yaptık."

5. "Kusurlarımızı açık bir biçimde Tanrı'ya, kendimize ve başkasına itiraf ettik".

6. "Tanrı'nın bu kişilik bozukluklarını düzeltmesi için tüm benliğimizle hazıllandık."

7. "Tanrı'dan eksikliklerimizi gidermesini alçak gönüllülükle diledik."

8. "Zarar verdiğimiz insanların listesini çıkardık ve hatalarımızı düzeltmeye istekli hale geldik."

9. "Daha önce zararımız dokunan kişilerden, onları veya başkalarını rahatsız etmeyeceğimizden emin olduğumuz zaman doğrudan özür diledik ve hatalarımızı mümkün olduğu kadar telafi ettik."

10. "Kişisel dökümümüzü yapmaya devam ettik ve hatalı olduğumuz zamanlar bunu derhal itiraf ettik".

11. "Dua ve meditasyon yoluyla, algıladığımız anlamdaki Tanrı ile bilinçli bağlantımızı geliştirmeye devam ettik. O'nun bize uygun gördüğü şeyleri anlamak ve bunları yerine getirmek için dua ettik."

12. "Bu basamakların sonucu olarak, ruhsal bir uyanışla, bu mesajı alkoliklere taşımaya ve ilkeleri bütün işlerimizde uygulamaya çalıştık" $(64,65)$ 
Burada sadece maddelere yer verdiğimiz bu basamakların her biri AA metinlerinde temellendirilmeye çalışımakta ve bir felsefeye dayandırımaktadır. Genel olarak on iki basamak süreci ile bütüncül olarak alkol sorunun üstesinden gelmeyi amaçlayan bilişsel bir farkındalık ve ruhsal bir değişimin yaratılmasına çabalanmaktadır (65).

\section{Adsız Alkolikler ve On İki Gelenek}

On iki basamak programı ile temel olarak amaçlanan bireysel iyileşme iken, on iki gelenek ile amaçlanan AA'nın bir kardeşlik oluşumu olarak varı̆̆ııı sürdürmesini sağlamaktır. AA'nın kurucuları tarafından ortaya atılan ve zaman içinde gelişstirilen bu ilkelerle amaçlanan, grubun dünya çapındaki varlığını sürdürmesi, grup üyelerinin birbirleri ve grupla olan ilişki ve bağlarının belirlenmesidir. Ayrıca AA on iki gelenek araciığıyla hem kendisini hem de sınırlarıı tanımlamaktadır (66). On ikinci gelenekte AA için önemli bir kavram olan adsızığın amacına ilişkin göndermede bulunulmaktadır. Bu bağlamda kişisellikten kaçınılmasına; grubun prensiplerinin ve iyiliğinin önplanda tutulmasına vurgu yapılmaktadır. Adsızlık ile alçak gönüllülük arasında sıkı bir bağ kurulması önemli bir amaçtır. Adsızlık üyelerin kendilerini güvende hissetmelerinin de önemli bir dayanağıdır $(52,65,66)$.

\section{Adsız Alkolikler: Gruplar ve Toplantılar}

Her bir AA grubunun bir adı ve belli bir toplanma yeri vardır. AA grupları diğer gruplarla iletişim kurabilir, değişiklikler ve mali konular için kendi sorumluluklarını alırlar. Sosyal aktivitelere ev sahipliği yapabilir ve çeşitli kurumlara, hastane ve hapishanelere ziyaretler gerçekleştirebilirler. Üyeler yeni gruplar oluşturabilirler; bunun için alkol sorunu olan iki üyenin varlığı ve birlikteliği yeterlidir. Üyeler bir grubun işleyişini ve toplantıların nasıl sürdürüldüğünü bu gruplarda yer alıp gözlemleyerek öğrenirler (60).

İki farklı toplantı şekli vardır. Bunlar açık ve kapalı toplantılardır. Açık gruplara AA üyeleri ve yakınları, arkadaşları ve grupla ilgilenen bireyler katılabilir, ancak AA üyelerinin kimliklerinin gizliliğinin sağlanması önemli bir koşuldur $(60,64)$. Kapalı gruplara sadece kendilerini AA üyesi olarak tanımlayanlar veya başka bir AA grubuna üye olanlar katılabilir. Kapalı gruplarda sadece bu sorunu yaşayanların anlayabileceği deneyimler paylaşılır ve bir etkileşim ortamı kurularak sorunların aşılması amaçlanır (63). Toplantılar birtakım ritüelleri içerir, ilk olarak açılış konuşması, daha sonra tartışmalar, içecek ikramı, para toplanması ve kapanış şeklinde bir dizge takip edilir. AA'da üyeler arasında eşitlik önemsenen bir ilkedir. Toplantılara ilişkin bazı genel kurallar mevcuttur (60).

Toplantılar genellikle 60-90 dakika sürmektedir. Toplantıya genellikle Adsız Alkolikler kitabından bölümler okunarak başlanır. Bazı gruplar kısa bir dua veya açılış mesajı da okuyabilirler. Bundan sonra grubun seyrini genellikle üyelerin deneyim ve yaşantılarının paylaşıması belirler. Ancak zaman zaman bir konu gündeme alınıp onun çevresinde bir grup sürdürülebilir. Grup üyelerinin ayıklıklarıyla ilgili önemli zamanlar (örneğin bir üyenin ayıkığının birinci ylı) bir kutlama sebebi olabilir. Toplantılarda on iki basamağa bağlı kalarak iyileşmeye odaklanmak, AA okumaları yapmak ve kişisel deneyimlerin paylaşımasının ardından açık tartışmalar yapılabilir (52).

Bilgisayar ve internetin yaygınlaşması ile birlikte online toplantılar da düzenlenmeye başlanmıştır. Bazı üyelerin bu ortamda kendilerini daha rahat hissettiği ve dünyanın herhangi bir yerindeki AA üyesi ile temas kurabildikleri ifade edilmektedir (52). Ayrıca yaşadığı bölgede AA grubu olmayan üyeler ya da gruplara katımalarını engelleyebilecek sorunları olanlar da bu tür grupları kullanmaktadıllar (67).

\section{Adsız Alkolikler: Sponsorluk ve Kardeşlik}

Yeni katılımcıların kendilerini rahat hissedecekleri ya da alkolden uzak kalmak konusunda kendilerini yakın gördükleri ve faydalanacaklarını umdukları üyelerle ilişki kurmaları teşvik edilir. Bu bir zorunluluk olarak sunulmaz. Üyelerin sorunlarına çözüm için sadece toplantıların değil, üyelerin kendilerini rahat ifade edebilecekleri bir eşit arkadaşlık ilişkisinin kurulabilmesi amaçlanır. Bu bağlamda bir üye herhangi başka bir üyeye kendisinin sponsoru olup olamayacağını sorabilir. Sponsorluk sorumluluğuna ilişkin yazılı bir kural tanımlanmamıştır, ancak on iki basamak programı ile uyumlu olarak iyileşmede önemli olduğu düşünülmektedir $(52,68)$. 


\section{Adsız Alkolikler: Üstün Güç Kavramı}

On iki basamak programı içerisinde Tanrı kavramı yer alıyor olsa da bunun üyelerin kendi anladıkları anlamda bir kavramı sembolize ettiği ifade edilmektedir (69). AA ancak kendilerini aşan bir güç kavramı sayesinde ruhsal gelişimlerini ve alkolden uzak durmayı başarabileceklerini ya da başarabildiklerini ifade etmektedirler. Böylece kendilerini aşan ve kendilerine yardımcı olabilecek yaratıcı bir akıl, evrenin ve her şeyin altında yatan bir güç kavramı ortaya çıkmıştır. Bu bağlamda bunun herkese açık bir anlama sahip olduğu ifade edilmiştir (66). Günümüzde ve kuruluş aşamasında AA'nın çok sayıla üyesinin herhangi bir inanca sahip olmadıkları belirtilmiştir. Herhangi bir dini aidiyetleri olmayan üyelerin AA gruplarından önemli ölçüde yararlandıkları ifade edilmiştir. Ayrıca AA'nın spiritüel söylemlerini yok sayarak gruptan faydalanan çok sayıda üyenin varlığı bilinmektedir (52).

\section{Adsız Alkolikler ve Sağlık Profesyonelleri Arasındaki Illişkiler}

AA, alkolizmi bir hastalık olarak tanıdıklarını, kendilerini psikiyatrist veya terapist olarak görmediklerini, ilaç yazma, danışmanlık verme gibi yetkilerinin olmadığını ve tanı koyamayacaklarını ifade etmektedirler (70). AA kuruldukları günden itibaren profesyoneller ile iyi ilişkiler kurmayı amaçlayan bir görünüme sahiptir. AA profesyonellerden gelen öneri ve katkıları dikkate aldığını sıkça vurgulamakta, aynı zamanda profesyonellerin de kendi deneyimlerinden faydalanabileceğini ifade etmektedir (70). AA özellikle kurulduğu ilk dönemde bağımlılığa ilişkin profesyonel bakışı önemli ölçüde etkilemiştir.

AA ile edinilen deneyim sağlık profesyonellerini etkilemiş ve sosyal temelli iyileşme programlarının oluşturulmasına katkıda bulunmuştur. Bunun dışında da çok sayıda on iki basamak grubunun oluşması aşamasında örnek alınmıştır. Daha önce de ifade edildiği gibi, Al-anon (Alkolik aileleri), Adsız Narkotikler, Adsız Kumar Bağımlıları bunlardan bazılarıdır. Minnesota'da yer alan Willmar State Hospital Adsız Alkolikler ile sağlık profesyonellerinin etkileşiminin başladığı yerdir. Profesyonellerin deneyimlerinden gelen bilgiler ile AA'nın deneyimlerinden gelen pratikler birleştirilmiş ve Minnesota modeli doğmuştur. Sonrasındaki çalışmalar bu sayede bağımlılık tedavisinde daha başarılı olunduğunu göstermiştir. Minnesota modeli sayesinde, profesyonellerin uyguladığı bilişsel-davranışçı yaklaşımlar ve motivasyon artırma girişimlerine üçüncü bir yaklaşım olarak on iki basamağın önerileri eklenmiştir. Bu bağlamda profesyoneller AA ve NA (Adsız Narkotikler) gibi gruplar hakkında hastaları bilgilendirmeyi uygun görmüş ve bu gruplara katılmalarını teşvik etmişlerdir (62). Günümüzde Amerikan Psikiyatri Birliği gibi kuruluşlar AA gibi grupları tedavinin önemli bir parçası olarak görmektedirler (52).

\section{Türkiye'de Adsız Alkolikler}

AA 1940'lardan itibaren Dünya'da tanınır olmaya başlamıştır. Türkiye'de AA grupları görece geç kurulup faaliyet göstermeye başlamıştır. Türkiye'de AA'nın kurulması ve yaygınlaşması 1988 yılına dayanmaktadır. IIlk toplantıların başlatılığı yıl olan 1988, AA'nın Türkiye'deki tarihsel başlangıcını temsil etmektedir. AA'yı yurtdışında öğrenmiş ve üyesi olmuş bireyler ile Ege Üniversitesi Tıp Fakültesi Psikiyatri Birimi arasındaki iletişim sonucunda 1988 yılında AA, Ege Üniversitesi Psikiyatri Biriminde haftalık tanıtım toplantıları düzenlemeye başlamıştır. Aynı yıl içerisinde İstanbul ve Ankara'da da gruplar kurulmuştur. 1989 yılına gelindiğinde ise Türk ve Amerikan AA üyelerinin düzenlemiş olduğu konvansiyon sonrasında AA Türkiye'ye yayılmaya başlamıştır.

AA'nın Türkiye'de kurulma sürecinde Türkiye dışında $A A$ üyesi olup Türkiye'ye gelen üyelerin önemli katkıları olmuştur. Bu üyeler başlangıçta Türkiye'de AA gruplarının varlığı konusunda hayal kırıkı̆̆ına uğramışlardır. Örneğin bir üye İstanbul'da daha önceden Amerikan Hastanesi'nden bir doktorun katkıları ile bir grup kurulmuş olduğunu öğrendiğini, ancak Türkive'ye geldiğinde bu grubun devam etmemiş olduğunu belirtmiştir. Yine aynı üye Amerikan Hastanesi'nde toplantı ve tanıtım için yer talebinde bulunmuş ve bu talepleri olumlu karşılanmıştır. Ancak bu girişim başarılı bir şekilde sonuçlanmamıştır (71).

Ancak 1988 yılında AA adına olumlu gelişmeler yaşanmıştır. Özellikle Avrupa merkezli büyük toplantılarda tanışan Türk üyeler Türkiye'de de grubun kurulmasına aracılık etmişlerdir. Örneğin Ankara'da bir toplantı 
gerçekleştirerek kaynakların Türkçeleştirilmesi konusunda çalışmışlardır. Eylül 1988'de İzmir'de az sayıda üye tarafından forumlar ve toplantılar düzenlenmeye başlanmıştır (71). Ankara'da ilk grup toplantılarının Ingilizce kaynaklara bağlı kalınarak Ingilizce yapıldığı ancak 1990 yılında ilk olarak Amerikan Kültür Derneği'nden kiralanan bir odada 7-8 kişiyle başlayan Türkçe toplantıların zamanla büyüdüğü ve mekanın yetersiz gelmesi üzerine Sıhhiye'de kiralanan yere taşınıldığı belirtilmiştir (71).

AA Türkiye Genel Hizmet Komitesi ise 2001 yllında kurulmuştur $(63,64)$. Bu çalışmanın gerçekleştirildiği sırada, AA Türkiye verilerine göre Ankara, İstanbul, İzmir, Muğla, Bursa gibi şehirlerde birden fazla olmak üzere Türkiye'de 28 AA grubu vardır (67).

AA Türkiye, dünyadaki diğer AA gruplarına benzer bir iç işleyiş ve toplantı metoduna sahiptir. AA'nın önemli yayınlarının başında gelen, Alcoholics Anonymus (Big Book) - Adsız Alkolikler ve Twelve Steps and Twelve Traditions - On İki Basamak ve On İki Gelenek gibi eserler Türkçeye çevrilmiş ve basıımıştır (72). AA grup toplantıları dışında büyük çaplı bölge toplantıları, ulusal büyük toplantılar ve uluslararası toplantılar düzenlemektedir (73).

Adsız Alkolikler Türkiye, diğer kendine yardım gruplarına oranla önemli ölçüde gelişim kaydetmiş olsa da AA'nın kuruluş ve Türkiye'de kabul görme sürecinin güç olduğu ve bu güçlüklerin bugün de devam etmekte olduğu düşünülmektedir. AA'nın tüzel bir kişiliği ve kurumsal bir yapısı olmadığından çalışma kapsamında ulaşılan bir AA üyesinin kişisel arşiv belgeleri çalışma için değerli olmuştur (74). Belgelerin incelenmesi sürecinde aynı AA üyesi ile kısa bir röportaj gerçekleştirilmiş ve bu röportajdan elde edilen verilerin AA'nın Türkiye'deki tarihsel gelişimini göstermek bakımından önemli olduğu düşünülmüştür (75). Bu bağlamda bu AA üyesi gönüllü olarak verdiği bilgilerin çalışmada kullanılmasına izin vermiş ve $A A^{\prime}$ 'nın tanıtımı açısından da önemli olduğunu belirtmiştir.

Yıllardır ayık olduğunu ifade eden M., AA ile tanışmasını "mezardan çıkmaya" benzetmiştir. Ancak Türkiye'de AA'ya genel olarak olumlu bir yaklaşımın olmadığını sözlerine eklemiştir. Hastaların kendilerini hasta olarak ifade etmelerinde AA'nın önemli katkılarına değinen M., AA'dan önce alkolizmin hastalık olarak hastalar tarafından kabul edilmesinin oldukça güç olduğuna değinmiş̧ir. Ancak benzer bir problemin sağık çalışanları için de geçerli olduğunu ifade etmiştir (75). Bu bağlamda verdiği bir örneğin çarpıcı olduğu düşünülmüştür:

"Bir arkadaşımız kaydı, biliyorsunuz bizde genellikle nüks için kaymak ifadesi kullanılır. Sonra alkolik olan üç arkadaş onu AMATEM'e tedavi olması için götürdük. Arkadaşımız zangır zangır titremeye başladı, biliyorsunuz yoksunluğa girmişti. Uzman doktor geldi. "Arkadaşımız alkolik ve sanırı yoksunluğa girdi" dedik. Hocaya "ben de alkoliğim" dedim. Doktor; "demeyin öyle" dedi. Üçümüz de "alkoliğiz" dedik, ama Israrla "öyle demeyin" dedi. Yani demem o ki alkolikliğimizi kabul etmedi. Daha sonra doktor, hastaya "git 3 gün sonra gel" dedi. Arkadaşım ise 'ben 3 gün değil 3 saat ayık kalabilsem size ne intiyacım var' deyip gitti. Yani doktorlara bile alkolizm anlatılı diyebilirim."

Az da olsa olumlu örneklerin de mevcut olduğunu ifade eden M., kendisinin de AA ile tanışmasını bu olumlu örneklere dayandırmıştır:

"Ancak AA'nın önemini kavrayan hocalar da vardı." ... "Beni de AA'ya yönlendiren hoca şöyle demişti; 'biz detoksu tamamladıktan sonra hastayı nereye bırakıyoruz... yine arkadaşlarının içine bırakıyoruz"

Kurumsal düzeyde Türkiye'de AA'nın profesyonelleri önemsediğini ifade eden ve bu bağlamda Türkiye'de yaşanan süreci anlatan M., şu ifadeleri kullanmıştır:

"AA bazı üniversitelerce ve birimlerce iyi karşılanıyor, tanıtım toplantılarına ve diğer toplantılara katılmalarına izin veriliyor. Fakat bazıları karşılarında tüzel bir kişilik görmek istiyor. İstanbul'da üniversiteler biraz daha destekleyici, Ankara'da Gazi'de toplantılar yapıyoruz. Ama sorun sadece AA ile ilgili değil, bazı bağımlılık servisleri kapatıld..”

Diğer gruplardan da örnek vererek, bağımlılı̆a yaklaşım ve kendine yardım gruplarının Türkiye'deki durumuna ilişkin olarak şu ifadelere yer verilmiştir. 
"AA geleneğinden doğmuş başka gruplar da var örneğin NA (Adsız Narkotikler). Bir dönem desteğimizle toplanıyorlardı. Ama genel olarak yer bulmakta, kabul görmekte sorunlar var. En son bir kilise toplanmaları için yer vermişti. Bildiğim kadarıyla şu an toplanamıyorlar"

"Kabul görme sorunu AA için de var, ancak Türkiye'de daha uzun bir tarihleri ve gelenekleri oluştu. Kendi kendimize yetip gitmeye çalışıyoruz." Örneğin Amerika'da AA üyesine birinci sınıf vatandaş gözüyle bakllıyor bizde ise durum böyle değil."... "Ankara'da Kızılay ve Sıhhiye grupları var." (75).

Görüşülen AA üyesinin anonimleştirerek verdiği belgelerde AA üyelerinin de kurulma dönemine ilişkin ifadelerine ulașılmıştır. AA için anonimlik oldukça önemli bir kavram olduğundan biz de tekrar anonimleştirerek konuya ilişkin bilgilere yer verdik. Adsı Alkolikler üyesi olan X Gazi Hastanesi'nde gerçekleştirilen AA tanııı toplantıları sayesinde 1990'ların başında AA ile tanıştığını ifade etmiştir. Buradaki toplantılar sayesinde AA gruplarının oluştuğuna değinen $X$ sonrasında AA için yer arayışlarına girildiğini ve farklı mekanlarda toplantılar düzenlediklerini beliitmiştir. Uzunca bir süre çay bahçeleri gibi açık alanlarda toplantılar gerçekleştirildiği söylemiştir. Bu bağlamda Turizm Bakanlığı'nın Ulus'ta Eski Türkiye Büyük Millet Meclisi'nin altındaki bahçede toplanılmasına izin verdiğine değinilmiştir. Amerika'ı üyelerle Conrad Otel'de yapılan İngilizce toplantılardan bahseden X, 1991 yılında Amerikan Kültür'ün iki aylığına kendilerine bir oda verdiğini ve haftanın üç günü toplantı gerçekleştirdiklerini ifade etmiştir. Bu toplantılarda kullanabildikleri temel materyalin AA Hayat Hikayeleri adlı eser olduğuna değinmiştir. 1992 yllında ise mekânın yetmemesi ile birlikte Sıhhiye'de kiralanan bir daireye geçilmiştir. X özellikle ilk dönem yaşanan maddi sorunlardan, toplantılarda çıkan tartışmalardan da bahsetmiş̧ir (74).

Aynı belgelerde bir başka AA üyesi olan W o dönem Gazi Hastanesi'nde AA toplantılarının düzenlendiğini ifade etmiştir. X ile benzer anlatımlara yer veren W 1990'ların başlarında Ankara ve İstanbul AA'nın kuruluşu ile ilgili olarak gazetelerde haberler yer aldığına değinmiştir. Bir dönem AA'nın misyonerlik suçlamalarıyla da karşılaştığına işaret etmiştir. Yayınlar konusuna da değinen W, İngilizce olan Büyük Kitap'ın Ankara, İzmir ve İstanbul'da üyelere dağıtılarak çevrildiğini belirtmiştir. Çeviri Amerika'ya gönderilmiş 500 ya da 1000 adet basılmıştır (74).

\section{Adsız Alkolikler ile İlgili Çalışmalar}

AA, alkoliklerin damgalanmamasına yönelik başarısı ve alkol bağımlı̆̆ğı sorununun uzun süreli tedavisine katkılarından dolayı 1951 yılında Amerikan Halk Sağlığı Birliği tarafından verilen Lasker Ödülü’ne layık görülmüştür (76). Yapılan çalışmalarda AA'nın tıbbi pratiğin dışında en sık başvurulan yapılardan olduğu ve hem kadınlar hem de erkekler tarafından sıkça kullanıldığı belirtilmiştir. Ancak bu başvuruların tıbbi desteği azaltmadığı, aksine tıbbi desteği güçlendiren bir fonksiyon taşıdığına değinilmiştir. Bu bağlamda sıkça üzerinde durulan nokta, AA'nın özellikle tıbbi tedavi sonrasındaki bakıma önemli katkılar sağladığı ve tıbbi tedavi başarısını arttırdığıdır (77).

Çok sayıda çalışmada, AA'ya devam eden bireylerde içmeme oranlarının yüksek olduğu ve AA'nın ilaçla tedavileri olumlu etkilediği görülmüştür (78). Profesyonel destek ve AA gibi yardım gruplarının birlikte kullanılmasının uzun süreli ayıkığı sağlamada oldukça başarılı olduğuna değinilmektedir (79). AA gruplarına katılmanın sadece sorun yaşayan bireyler için değil, bu bireylerin aile üyeleri için de olumlu etkilere sahip olduğu belirlenmiştir (80). Çalışmalarda AA'ya üye olmanın üyelere ne şekilde fayda sağladığına bakıldığında; AA'ya katılımın, alkolden uzak durmaya ilişkin motivasyonu sürdürmeye yardımcı olduğu, ayıklığı sürdürmekle ilgili yetenek ve baş etme stratejilerini artırdığı, ayıkığı sürdürecek şekilde sosyal ilişkileri güçlendirdiği şeklinde bulgulara ulaşılmıştır (52.81). AA'nın tedavi sırasında ve sonrasındaki etkinliği sayesinde tedavi maliyetlerinin düşmesinde de önemli rol oynadığı belirlenmiştir $(82,83)$.

\section{Sonuç}

Günümüzde önemli bir sağlık sorunu olan bağımlılı̆ın alkol özelinde tarihsel süreci ve bu süreçte önemli bir aktör olarak ortaya çıkan AA grubunun gelişimi incelenmiştir. Bağımlılık gibi süreğen niteliğe sahip sağlık 
sorunlarının çözümünde akut önlemler kadar uzun sürece yayılmış olan toplum destekli yaklaşımların etkinliği düşünüldüğünde AA gibi kendine yardım gruplarının önemli roller üstlendiği görülmüștür. Ancak AA grubunun başarılı olmasında sağlık profesyonelleri ile karşıllklı etkileşimlerinin önemli bir etken olduğunu söylemek mümkündür.

Bu hareketin en önemli özelliklerinden bazılarını, alkol karşıtı bir hareket olmayışı, profesyonel ve bilimsel yöntemlerle uzlaşı içinde oluşu, üyelerine eşitlik içinde yaklaşması ve spiritüel bir kimliğe sahip olmakla birlikte herhangi bir özel aidiyet taşımıyor oluşu oluşturmaktadır. Bu özellikleri yanında hem tek tek üyeleri ve hem de grubun bütünü yararına oluşturduğu felsefi arka planının da sağlam olduğu görülmüştür. Bu özellikleri sayesinde başka gruplar tarafından da örnek alınmış ve farklı toplumsal kesimlere yol gösterici olmuştur. Özellikle çalışmalarca da desteklenmiş olan bağımlılığın uzun süreli seyrindeki olumlu etkileri sayesinde günümüzde sağlık profesyonelleri tarafından önerilen ve desteklenen bir yapı haline gelmiştir. Tüm bu nitelikleri sayesinde AA dünya çapında en büyük kendine yardım grubuna dönüşmüştür. Türkiye özelinde de AA'nın bağımlılık alanında önemli bir oluşum olduğu görülmüştür. Ancak edinilen bilgiler kısıtlı olmakla birlikte AA'nın ülkemizdeki olumlu çabalarına rağmen toplumsal kabulünün düşük olduğu izlenimi edinilmiştir.Sonuç olarak 1935 yılında kuruluşu ile birlikte modern anlamda kendine yardım gruplarının başlangıcı olarak görülen AA, aynı zamanda bilimsel olarak bağımlıık alanındaki çalışmaların başlamasına da katkıda bulunmuştur. Böylece bağımlılık sorunu yaşayan pek çok bireyin yaşamını olumlu etkilemiştir.

\section{Teşekkür}

Çalışma aşamasındaki destekleri için Ankara Üniversitesi Tıp Fakültesi emekli öğretim üyesi Prof. Dr. N. Yasemin Yalım'a ve Gazi Üniversitesi Tıp Fakültesi öğretim üyesi Prof. Dr. Zehra Arıkan’a teşekkürlerimi sunarım.

Bu makale araştırmacı tarafından Ankara Üniversitesi Tıp Fakültesi Tıp Tarihi ve Etik Anabilim Dalı'nda 2018 yllında sunulan tıp tarihi seminerine dayanmaktadır.

\section{Kaynaklar}

1. Jaffe $J H$, Anthony JC. Madde Kullanımına Bağlı Bozukluklar: Giriş ve Genel Bakıs, Aydın H, Bozkurt A (Çevirenler). Sadock BJ, Sadock VA (editors). Kaplan and Sadock's Comprehensive Textbook of Psychiatry Cilt 2. 8. Baskı, Ankara: Güneş Kitabevi, 2007: 1137-1168.

2. Gateley I. Drink: A Cultural History of Alcohol. New York: Goatham Books, 2008.

3. American Psychiatric Association. Diagnostic and Statistical Manual of Mental Disorders (DSM-5). $5^{\text {th }}$ edition. Washington DC: American Psychiatric Association, 2013: 490-497.

4. Hanson DJ. Historical evolution of alcohol consumption in society. Boyle P, Boffetta P, Lowenfels AB, Burns $H$, Brawley 0, Zatonski W, Rehm J (editors). Alcohol: Science, Policy, and Public Health. Oxford: Oxford University Press, 2013: 56-80.

5. Tracy SW. Alcoholism in America From Reconstruction to Prohibition. Baltimore: Johns Hopkins University Press, 2005: 1-24.

6. Gold MS, Adamec C. Introduction: a history of alcohol abuse and dependence. The Encyclopedia of Alcoholosm and Alcohol Abuse., New York: Infobase Publishing, 2010: xiii-xliii.

7. Öztürk MO, Uluşahin NA. Ruh Sağlğı ve Bozuklukları. 14. Baskı, Ankara: Nobel Tıp Kitabevleri, 2016: 511-544.

8. Mariani JJ. Alkolle lilişkili Bozukluklar, Özdel K (Çevirenler), Apteki K, Öztürk Ö (Çeviri Ed.). Gabbard GO (editor). Gabbard's Treatments of Psychiatric Disorders. 4. Baskı, Ankara: Veri Medikal Yayınclık, 2009; 199-206.

9. Lukas SE. Alcohol. Carson-Dewitt R (editor). Encyclopedia of Drugs, Alcohol, and Addictive Behavior Volume 1. $2^{\text {nd }}$ edition, New York: Macmillan Reference, 2001: 70-74.

10. AAALAC. Alcohol as a disinfectant. https://www.aaalac.org/pub/?id=10D85285-0BC6-F7F1-FC83B9444659A4E6. (23 Kasım 2017 tarihinde ulaşıldı).

11. Braidwood RJ, Sauer JD, Helbaek H, et al. Symposium: did man once live by beer alone? Am Anthropol 1953; 55: 515-526.

12. Phillips R. Alcohol A History. Chapel Hill: The University of North Carolina Press, 2014.

13. Million M. Wine: A Global History. London: Reaktion Books, 2013. 


\section{Bağımlılık Dergisi - Journal of Dependence}

14. Lutz HF. Viticulture and Brewing in The Ancient Orient. New York: Leipzig J C Hinrichs'sche Buchhandlung, 1922: 25.

15. Johns CHW. Babylonian Law - The Code of Hammurabi. https://sourcebooks.fordham.edu/Halsall/ancient/hamcode.asp (21 Kasım 2017 tarihinde ulaşıldı).

16. Hames G. Alcohol in World History. $2^{\text {nd }}$ edition. New York: Routledge, 2014: 50-52.

17. Plato. Book II, Pangle TL (Çeviren). The Laws of Plato. $3^{\text {rd }}$ edition. Chicago: The University of Chicago Press, 1988: 56-57.

18. Jellinek EM. Drinkers and alcoholics in ancient Rome. J Stud Alcohol 1976; 37: 1718-1741.

19. Majeed A. How Islam changed medicine Arab physicians and scholars laid the basis for medical practice in Europe. BMJ 2005; 331: 1486-1487.

20. Martin AL. Alcohol, Sex, and Gender in Late Medieval and Early Modern Europe. New York: Palgrave, 2001: 4, 42.

21. Knap VJ. Alcohol, industrilization and high-energy foods. Bull NY Acad Med 1988: 64: 430-434.

22. Blocker JS, Fahey DM, Tyrrell IR. Preface. Alcohol and Temperance in Modern History An International Encyclopedia. Santa Barbara: ABC-CLIO, 2003: xxiii-xxiv.

23. Lesch O-M, Walter H, Wetschka C, et al. Alcohol and Tobacco: Medical and Sociological Aspects of Use, Abuse and Addiction. Mörlenbach: SpringerWien NewYork, 2011: 5-14.

24. Comer J. Distilled beverages. Kiple KF, Orneals KC (editors). The Cambridge World History of Food. Cambridge: Cambridge University Press, 2000; 653-663.

25. Bhugra D, Winston M. Alcohol and alcohol-related problems in Caraka Samhita. Hist Psychiatry 1994; 5: 347360.

26. Filed RC. Cruciferous and green leafy vegetables. Kiple KF, Orneals KC (editors). The Cambridge World History of Food. Cambridge: Cambridge University Press, 2000; 290.

27. Smith I. The birth of addiction. Hist Psychiatry 2010; 21: 351-355.

28. Glaser FB. Alcoholism: origin of the term. Carson-Dewitt R (editor). Encyclopedia of Drugs, Alcohol, and Addictive Behavior Volume 1. $2^{\text {nd }}$ edition, New York: Macmillan Reference, 2001: 101-104.

29. Skog 0-J. The long waves of alcohol consumption: a social network perspective on cultural change. Soc Networks 1986; 8:1-32.

30. Ateşçi FÇ, Kuloğlu M, Tezcan E, Yıldız M. İntihar girişimi olan bireylerde birinci ve ikinci eksen tanıları. Klinik Psikiyatri Dergisi 2002; 5: 22-27.

31. Ünal S, Özcan E. Depresyonda hazıllayıcı, ortaya çıkarıcı ve koruyucu etkenler. Anadolu Psikiyatri Derg 2000; 1: 41-47.

32. Moussas G, Papadopoulou A. Substance abuse and cancer. Psychiatriki 2017; 28: 234-241.

33. Bertelli AAE. Wine, research and cardiovascular disease: instructions for use. Atherosclerosis 2007; 195: 242247.

34. World Health Organization (WHO). Global Status Report on Alcohol and Health 2014. Geneva: WHO, 2014.

35. Nutt DJ, Nestor LJ. Addiction. Oxford: Oxford University Press, 2013: 19-29.

36. Baler RD, Volkow ND. Drug addiction: the neurobiology of disrupted self-control. Trends Mol Med 2006; 12: 559-566.

37. Helzer JE. Klinik Geçerliği Olan Boyutlar DSM-5’e Katma Önerisi, Alpagut Ş, Yüksel G, Azizoğlu F (Çevirenler), Şar V (Çeviri Ed.). Regier DA, Narrow WA, Kuhl EA, Kupfer DJ (editors). DSM-5'in Kavramsal Gelişimi. İstanbul: 121 Medikal Yayıncilık, 2011: 83-84.

38. World Health Organization (WHO). Turkey. Global Status Report on Alcohol and Health 2018. Geneva: WHO, 2018: 295.

39. Skinner HA, Holt $S$, Schuller R, et al. Identification of alcohol abuse using laboratory tests and a history of trauma. Ann Intern Med 1984; 101: 847-851.

40. Babor TF, Hernandez-Avila CA, Ungemack JA. Substance-related disorders: alcohol-related disorders. Tasman A, Kay J, Lieberman JA, et al. (editors). Psychiatry. $4^{\text {th }}$ edition. Oxford: Wiley-Blackwell, 2015: 1401-1434.

41. Johnson MB. Support groups. Fisher GL, Roget NA (editors). Encyclopedia of Substance Abuse Prevention, Treatment \& Recovery 1\&2. Los Angeles: SAGE Publications, 2009: 889-894.

42. Kurtz LF. Self-help and Support Groups: A Handbook for Practitioners. SAGE Publications, 1997: 1-16.

43. Fisher MS. Groups for Substance abuse treatment. Garvin CD, Gutiérrez LM, Galinsky MJ (editors). Handbook of Social Work with Groups. New York: Guilford Press, 2004: 259-274.

44. LaPaglia D, Kiluk B, Fucito L, et al. Substance use disorders and systems of care. Jacobs SC, Steiner JL (editors). Yale Textbook of Public Psychiatry. New York: Oxford University Press, 2016: 79-81. 
45. Humphreys K, Wing S, McCarty D, et al. Self-help organizations for alcohol and drug problems: toward evidence-based practice and policy. J Subst Abuse Treat 2004; 26: 151-158.

46. Shorkey C, Uebel M. Secular organizations for sobriety/save our selves. Fisher GL, Roget NA (editors). Encyclopedia of Substance Abuse Prevention, Treatment \& Recovery 1\&2. Los Angeles: SAGE Publications, 2009: 815-816.

47. George RP, Richards DAJ. The Eighteenth Amendment. https://constitutioncenter.org/interactiveconstitution/amendments/amendment-xviii (Accessed 23.12.2017).

48. George RP, Richards DAJ. The Twenty-First Amendment. https://constitutioncenter.org/interactiveconstitution/amendments/amendment-xxi (Accessed 23.12.2017).

49. White WL, Callahan JF. Addiction medicine in America: its birth and early history (1750-1935) with a modern postscript. Ries RK, Fiellin DA, Miller SC, Saitz R (editors). The ASAM Principles of Addiction Medicine. $5^{\text {th }}$ edition. Philadelphia: Wolters Kluwer Health, 2014: 365-374.

50. Humphreys K. Circles of recovery: self-help organizations for addictions. Cambridge: Cambridge University Press, 2004: 1-33, 33-43.

51. General Service Office of Alcoholics Anonymous. A.A. Fact File. https://www.aa.org/assets/en_US/m24_aafactfile.pdf (Accessed 23.12.2017).

52. Kelly JF, McCrady BS. Twelve-step facilitation in non-specialty settings. Galanter M, Kaskutas LA (editors). Recent Developments in Alcoholism Volume 18: Research on Alcoholics Anonymous and Spirituality in Addiction Recovery. New York: Springer, 2008: 321-346.

53. Bluhm AC. Verification of C. G. Jung's analysis of Rowland Hazard and the history of Alcoholics Anonymous. Hist Psychol 2006; 9:313-324.

54. Kenny MC, Winick CB. Bill W. Fisher GL, Roget NA (editors). Encyclopedia of Substance Abuse Prevention, Treatment \& Recovery 1\&2. Los Angeles: SAGE Publications, 2009: 123-124.

55. Kurtz LF. Recovery Groups. New York: Oxford University Press, 2015: 30-34.

56. A.A. This is A.A.: An Introduction to the A.A. Recovery Program. New York: Alcoholics Anonymous World Services, 2017: 1-19.

57. A.A. Estimated Worldwide A.A. Individual and Group Membership. 2016. https://www.aa.org/assets/en_US/smf-132_en.pdf.

58. A.A. 2020 International Convention of Alcoholics Anonymous. 2017. https://www.aa.org/pages/en_US/ (Accessed 4.12.2017).

59. Pittman B. Practice These Principles and What Is the Oxford Group? Oxford: Hazelden Publishing, 1997: 1-14.

60. Borkman T. The Twelve-step recovery model of AA: a voluntary mutual help association. Galanter M, Kaskutas LA (editors). Recent Developments in Alcoholism Volume 18: Research on Alcoholics Anonymous and Spirituality in Addiction Recovery. New York: Springer, 2008: 9-35.

61. Alcoholics Anonymous. What is the story behind the Circle and Triangle logo? https://www.aa.org/pages/en_US/frequently-asked-questions-about-aa-history\#cinco (Accessed 24.12.2017).

62. Borkman T. Introduction: the twelve-step program model of AA. Galanter M, Kaskutas LA (editors). Recent Developments in Alcoholism Volume 18: Research on Alcoholics Anonymous and Spirituality in Addiction Recovery. New York: Springer, 2008: 3-8.

63. Adsız Alkolikler Türkiye. Adsız Alkolikler Tanıtım Dosyası. Adsız Alkolikler Türkiye Genel Hizmet Ofisi; 1-23.

64. Adsız Alkolikler Türkiye. Adsız Alkolikler. http://www.adsizalkolikler.com/Tanitim.asp (Accessed 3.12.2017).

65. A.A. Twelve Steps and Twelve Traditions. New York: Alcoholics Anonymous World Services, 2012: 5-18.

66. A.A. Alcoholics Anonymous: The Story of How Many Thousands of Men and Women Have Recovered from Alcoholism. 4. Baskı. New York: Alcoholics Anonymous World Services, 2001: 44-57, 574-575.

67. Adsız Alkolikler Türkiye. AA Grup Listesi http://www.adsizalkolikler.com/Gruplar1.asp ((Accessed 18.05.2020)).

68. A.A. Questions and Answers on Sponsorship. New York: Alcoholics Anonymous World Services, 2005: 7-8.

69. Kurtz E. Not-God: A History of Alcoholics Anonymous. Minnesota: Hazelden Publishing, 2010: 153-172.

70. A.A. Eğer Profesyonelseniz. Turkish. New York: Alcoholics Anonymous World Services, 2000: 5.

71. Adsız Alkolikler Türkiye. Adsız Alkolikler'in Türkiye'de Illk Kuruluşu ile Illgili Belgeler. Adsız Alkolikler Türkiye Genel Hizmet Ofisi, 1994.

72. Adsı Alkolikler Türkiye. AA Kitaplar. http://www.adsizalkolikler.com/Download.asp?goster=kat\&kategori=7 (Accessed 12.12.2017).

73. Adsız Alkolikler Türkiye. Büyük toplantılar. http://www.adsizalkolikler.com/Toplantilar.asp?goster=kat\&id=24 (Accessed 18.12.2017).

74. Bir Adsız Alkolikler üyesine (M) ait kişisel belgeler. Adsız Alkolikler'in Türkiye'de Illk Kuruluşu ile Illgili Belgeler. (Accessed 13.12.2017). 


\section{Bağımlılık Dergisi - Journal of Dependence}

75. Yıldız A. Bir Adsız Alkolikler üyesi (M) ile yapılan röportaj. ((Accessed 13.12.2017)).

76. Albert and Mary Lasker Foundation. Historical Archive: Awards No Longer Given by the Foundation. Group Awards: 1951-Alcoholics Anonymous http://www.laskerfoundation.org/awards/show/historicalawards/\#[name=Group] ((Accessed 15.12.2017)).

77. Weisner C, Schmidt LA. Rethinking access to alcohol treatment. Galanter M (editor). Recent Developments in Alcoholism Volume15: Services Research in the Era of Managed Care. New York: Kluwer Academic Publishers, 2001: 111.

78. Brown SA, D'Amico EJ. Outcomes of alcohol treatment for adolescents. Galanter M (editor). Recent Developments in Alcoholism Volume15: Services Research in the Era of Managed Care. New York: Kluwer Academic Publishers, 2001: 314.

79. Timko C, Moos RH, Finney JF, Lesar MD. Long-term outcomes of alcohol use disorders: comparing untreated Individuals with those in alcoholic anonymous and formal treatment. J Stud Alcohol 2000; 6: 529-540.

80. O'Farrell TJ, Falls-Stewart W. Family-involved alcoholism treatment: an update. Galanter M (editor). Recent Developments in Alcoholism Volume 15: Services Research in the Era of Managed Care. New York: Kluwer Academic Publishers, 2001: 348.

81. Kaskutas LA. Alcoholics Anonymous effectiveness: faith meets science. J Addict Dis 2009; 28:145-157.

82. French MT. Economic Evaluation of Alcohol Treatment Services. Galanter M (editor). Recent Developments in Alcoholism Volume15: Services Research in the Era of Managed Care. New York: Kluwer Academic Publishers, 2001: 219, 223.

83. Humphreys $\mathrm{K}$, Moos R. Can encouraging substance abuse patients to participate in self-help groups reduce demand for health care? a quasi-experimental study. Alcohol Clin Exp Res 2001; 25: 711-716. 